\title{
Late Pleistocene glaciers to present-day snowpatches: a review and research recommendations for the Marrakech High Atlas
}

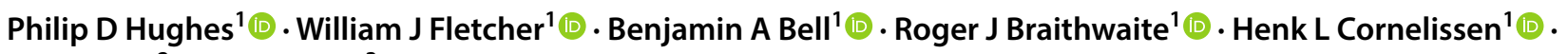 \\ David Fink ${ }^{2} \cdot$ Ali Rhoujjati $^{3}$
}

Received: 13 February 2020 / Revised: 13 April 2020 / Accepted: 15 April 2020 / Published online: 8 May 2020

(c) The Author(s) 2020

\begin{abstract}
There are no glaciers today in the High Atlas, Morocco. However, there is evidence that niche glaciers and late-lying snowpatches in the High Atlas were present as recently as the last century and there are at least four sites where snowpatches appear to survive some summer seasons today. Many other sites also support non-perennial late-lying snow below steep shaded north and northeast-facing cliffs at altitudes $>3100 \mathrm{~m}$. Coarse sediment ridges interpreted as moraines or pronival ramparts enclose most of these snowpatches. These landforms most likely record the positions of former niche glaciers and late-lying snowpatches in the Little Ice Age. The niche glaciers and late-lying snowpatches survived below the regional equilibrium line altitude because of strong local topoclimatic controls. In addition to strong shading, many of the current late-lying snowpatches are fed by long deep gullies which funnel avalanching snow from the cirque backwalls. The disappearance of many perennial snowpatches in the last few decades coincides with a strong trend towards warmer summer air temperatures since the $1970 \mathrm{~s}\left(>2{ }^{\circ} \mathrm{C}\right)$. However, inter-annual changes in snowpack mass balance are affected by very large variations ( $>400 \%$ variability) in winter precipitation. A new research programme is underway investigating the history of late-lying snow and cirque glaciers in the High Atlas. A particular focus of this research is to utilise geomorphological and geochronological evidence to understand fluctuations in snow and ice through the Holocene and link this to continuous records of environmental change in the High Atlas region.
\end{abstract}

Keywords Little Ice Age $\cdot$ Holocene $\cdot$ Glaciers · Snow $\cdot$ Moraines $\cdot$ Pronival ramparts $\cdot$ Toubkal $\cdot$ High Atlas · Morocco Africa

\section{Introduction}

The Atlas Mountains contain the highest peaks of North Africa. In 77 AD, Pliny the Elder described them as the "the most fabulous Mountains of Africa" and recalled the observations of Suetonius Paulinus, the first Roman commander to cross the Atlas, of an unknown summit as "covered with deep snowdrifts, even in summer" (Pliny translated in Rackham 1942, p. 223). Some of the earliest observations of glacial

Philip D Hughes

philip.hughes@manchester.ac.uk

1 Department of Geography, University of Manchester, Manchester M13 9PL, UK

2 Australian Nuclear Science and Technology Organisation, PMB1, Menai, Sydney, NSW 2234, Australia

3 Faculté des sciences et Techniques, Laboratoire Géoresources, Guéliz, BP 549, 40000 Marrakech, Morocco features in the Atlas Mountains were reported by Hooker and Ball (1878). Maw (1878) wrote a geological appendix in Hooker and Ball's (1878) book 'Journal of a tour in Marocco [sic] and the Great Atlas'. In later work, Thomson (1899, p. 205) was sceptical of some of Maw's glacial interpretations. Nevertheless, Thomson (1899, p. 199) noted that 'there is undoubted evidence of a Glacial period in the later history of the mountains, in the shape of moraine-heaps and ice-worn rocks and boulders in their glens and valleys'. Célérier and Charton (1922) and De Martonne (1924) reported glacial deposits in the headwaters of the Imenane and Rheraia (or Rhéraya) Valleys on the northern slopes of the Toubkal massif. In these valleys, De Martonne (1924) stated that former glaciers extended down to as low as $2000 \mathrm{~m}$ altitude and that the former snowline was situated at an altitude of $c .2800 \mathrm{~m}$.

No glaciers exist today in the High Atlas. However, latelying or perennial snowpatches (see Cogley et al. 2011 for terminology) do exist, the most famous being the Névé 
Permanent below the northern cliffs of the Tazaghart plateau (Hannah et al. 2017; Hughes 2014, 2018). The feature was first mapped as occupying a $0.5 \mathrm{~km}$ length of the gully and covering an area of at least 2 hectares on the detailed 1:20,000 1937 map of the Toubkal Massif presented in Delaye (1938), which is reviewed in Dusserre (2009). This feature was subsequently marked on topographic maps dating to the 1940s (US Army Map Service 1943), and was marked with the name Névé Permanent on the 1994 national 1:50,000 topographic map (Ministere de l'Agriculture et de la Mise en Valeur Agricole 1994). Long-lasting snowpatches (neiges éternelles) of the Tazaghart and nearby areas were also mentioned by Dresch (1941, p. 577). The survival of snow through the summer has also been noted in other areas of the High Atlas. For example, in the Tignousti Massif (3819 m) in the central High Atlas, Peyron (1980) noted that small snowpatches can persist into October buried under debris cover then overlain by the following winter's snow.

Snow in the Atlas Mountains has major economic and societal significance because of its role in regional hydrology as a significant source of groundwater as well as surface water recharge (N'da et al. 2016). Understanding the contribution of snow to catchment hydrology in the Atlas Mountains is of national strategic importance in a country largely characterised by a semi-arid climate, especially for water supply to crop irrigation the lowlands (Baba et al. 2019). Spatial variations in snow cover in the Atlas Mountains has been analysed using remote sensing (Chaponnière et al., 2005; Boudhar et al. 2010; Marchane et al. 2015). Several studies have also attempted to model the current snowmelt in the Atlas Mountains (e.g. Schulz and de Jong 2004; Boudhar et al. 2009, 2016; Baba et al. 2019) and incorporate this into catchment models of snowmelt runoff (Boudhar et al. 2009; Baba et al. 2019). This capacity to understand the potential contribution of snowmelt to the water supply is likely to become even more crucial to manage increasing demand on water supplies and also to mitigate the effects of climate change in this region (Parish and Funnell 1999).

Whilst it is recognised that glaciers were present in the Pleistocene and there has been increasing interest in snowmelt for contemporary hydrological studies, very little is known about the state of the cryosphere in the Atlas Mountains during the Holocene. Fluctuations in snow and ice in the Atlas Mountains directly impact on the fluvial regimes of rivers throughout most of Morocco (Boudhar et al. 2010). Understanding how snow and ice changes through time in the Atlas Mountains is crucial for understanding human development in the region. Today, snowmelt from the High Atlas represents the most important water storage for the crop irrigation in neighbouring arid plains (Baba et al. 2019) as well as drinking water and for sanitation in urban areas such as Marrakech, which supports a population of nearly 1 million residents as well as nearly 3 million tourists annually (Agence Marocaine de Presse 2020). Snowmelt, therefore, has direct implications for the economy. Droughts in the late twentieth century resulting from erratic snowfall in the Atlas caused reductions in the agricultural and total gross domestic product by $50 \%$ and $10 \%$, respectively (Diao et al. 2008), highlighting the significance of snowmelt for society in this region.

This paper aims at setting out a new research agenda to assess the nature and timing of Holocene glacier and snowpack dynamics in the High Atlas. This includes a review of the available evidence for recent nival and glacial activity in the High Atlas. It also includes a review of the wider context of Holocene environmental change in this region and highlights several hypotheses for when glaciers could potentially have formed in these mountains.

\section{Study area}

The Marrakech High Atlas is synonymous with the Massif Ancien du Haut Atlas described by numerous geologists (e.g. De Koning 1957; Proust 1973; El Archi et al. 2003), and separates the Western from the Central High Atlas and connects the Alpine domain of the High Atlas to the Hercynian and Panafrican domain of the Anti Atlas (Balestrieri et al. 2009). These mountains are formed in a complex suite of Precambrian basement volcanics (Pouclet et al. 2007) and are tectonically-active with active faulting characterised by the Tizi n'Test and Sour Fault Zones (Delcaillau et al. 2010; 2011). The igneous rocks consist of intrusive rocks, including a variety of grades of granites and diorites, and a thick stack of extrusive basaltic rocks including various grades of andesites, rhyolites and ignimbrites (Pouclet et al. 2007). Triassic sandstones and Cambrian limestones are present locally, although these lithologies have not been subject to glaciation (Hughes et al. 2018). The Marrakech High Atlas are dominated by Jebel Toubkal $(4167 \mathrm{~m})$ the highest peak in the Atlas Mountains. This massif was extensively glaciated during the Pleistocene (Fig. 1). This review focuses on the highest peaks of the area stretching from Adrar Meltsene $(3597 \mathrm{~m}$ ) in the east to Tazaghart (3980 m) in the west (Fig. 2).

The area experiences a strongly seasonal climate with very hot and dry summers and cool, wet winters. Average temperature and precipitation data for Marrakech $(466 \mathrm{~m})$ is presented in Fig. 3. Mean annual temperature is $19.4{ }^{\circ} \mathrm{C}$, with January being the coldest month $\left(5.5^{\circ} \mathrm{C}\right)$, and July the hottest $\left(36.3{ }^{\circ} \mathrm{C}\right)$. Mean annual precipitation is just $298 \mathrm{~mm}$, with most of this falling in winter. However, annual precipitation is highly variable, ranging from 142 to $570 \mathrm{~mm}$ (Fig. 4). Annual precipitation in the mountains at the ski resort of Oukaimeden (Club Alpine Française [CAF] station at c. $2600 \mathrm{~m}$ ) was $520 \mathrm{~mm}$ over the 1989-2010 period, with high interannual variability and a high proportion (c. $50 \%$ ) falling as snow (Boudhar et al. 2016). The variation 


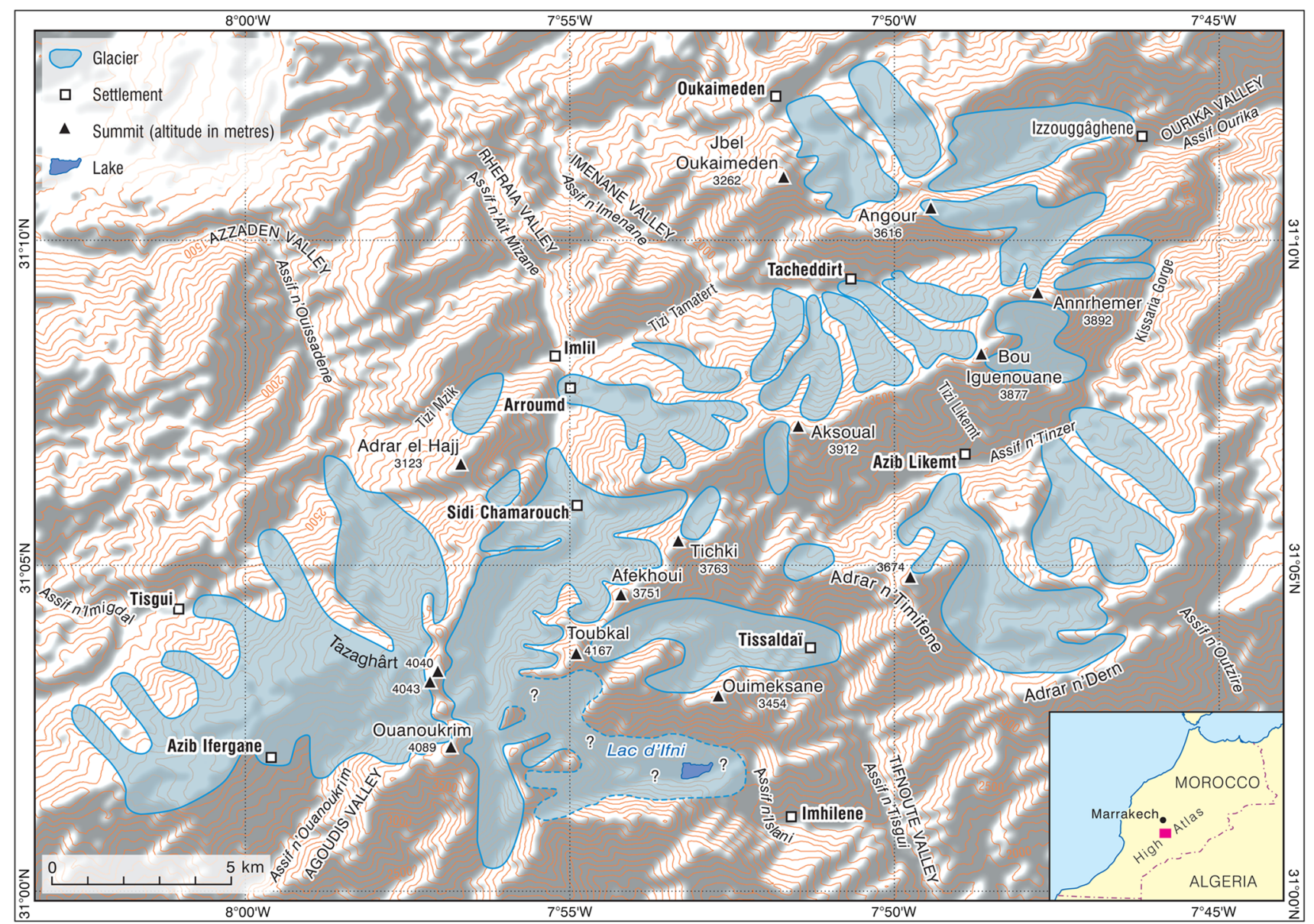

Fig. 1 Location map showing the maximum extents of Pleistocene glaciers in the High Atlas. Modified from Hughes et al. (2018) and Hughes et al. (2020). Contours are at $100 \mathrm{~m}$ intervals

in annual precipitation at several stations in the Marrakech High Atlas is illustrated in Fig. 5. The highest areas of Toubkal at c. $4000 \mathrm{~m}$ experience estimated mean annual temperatures of c. $-1.5^{\circ} \mathrm{C}$ and precipitation of c. $1000 \mathrm{~mm}$ (Hannah et al. 2017).

\section{Methods}

\section{Geomorphology}

The high cirques and valleys of the Marrakech High Atlas have been visited on 26 separate occasions by our research team since 2007 following an initial 2-week expedition visiting numerous high cirques and peaks of the central Jebel Toubkal area in August/September 1994 (Hughes et al. 2004). In addition to this, there have been several visits to the highest cirques to observe snow conditions by students and staff (see acknowledgements). This has allowed observations at different times of the year under different conditions on the highest areas, including in late summer and autumn at the end of the melt season. The Pleistocene glacial record has now been mapped in detail (Hannah et al. 2017; Hughes et al. 2018). Several of the highest cirques have been visited in late summer/autumn around the highest peaks of Toubkal (4167 m); Ouanoukrim (4089 m), Aksoual (3912 m) and Tazaghart (3980 m). The geomorphology of these and neighbouring cirques was also observed using satellite imagery: GeoEye-1 high-resolution satellite (DigitalGlobe 2020) and Google Earth historical imagery. Key features that were used to identify the most recent glacier and snow patch sites included moraines and pronival ramparts as well as the presence of snow in late summer/early autumn. Future work will also involve a detailed mapping of these high-level sites. Differentiating between moraines and pronival ramparts is often difficult (Hedding 2016) in the same way that late-lying snowpatches are difficult to differentiate from glacierets (Cogley et al. 2011). However, this has already been achieved for some sediment ridges on the basis of detailed geomorphological mapping and sedimentological characteristics (e.g. Hannah et al. 2017). The position of the sediment ridges relative to the cirque backwall is also 


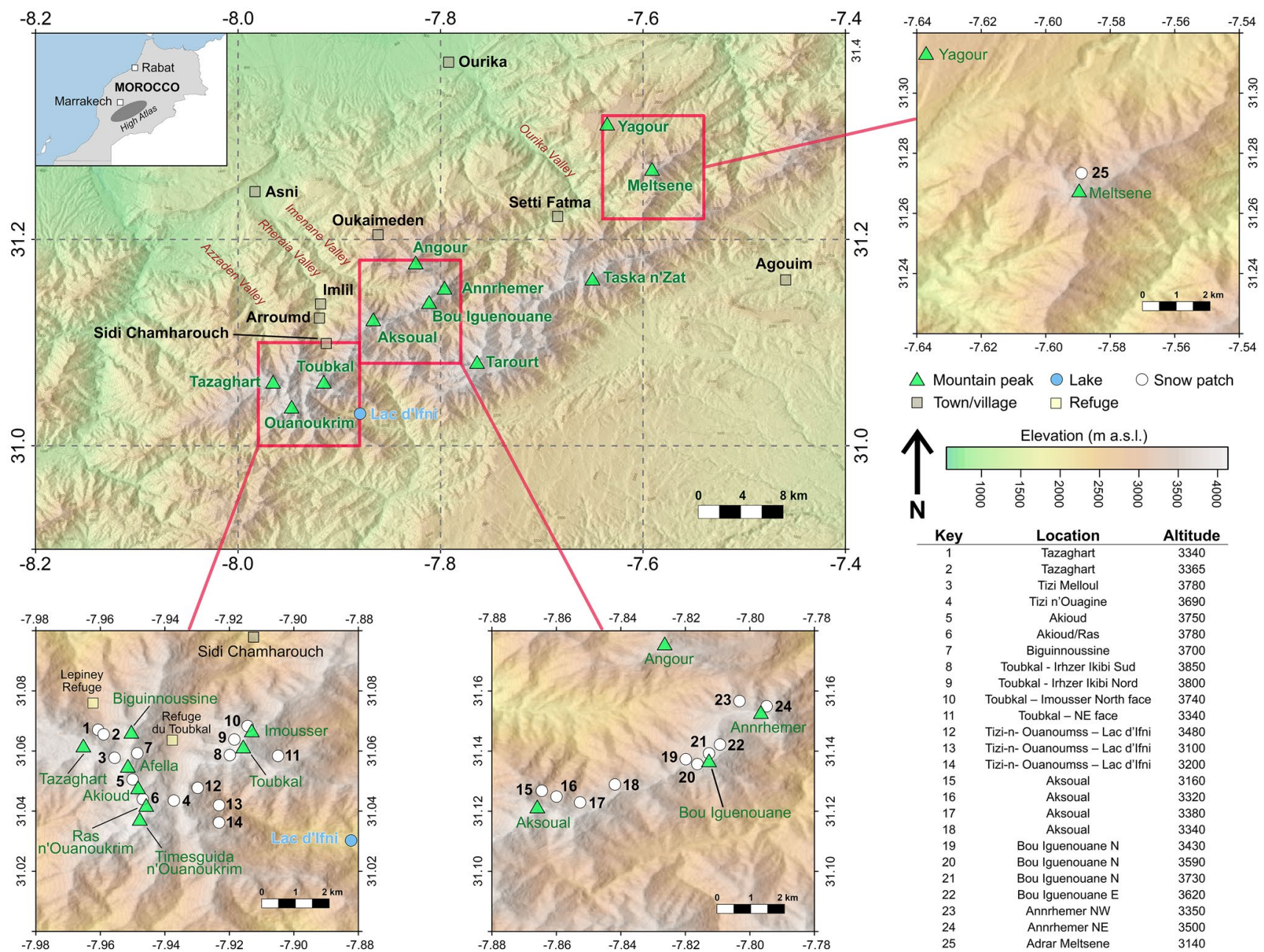

Fig. 2 Location maps showing the positions of current late-lying snowpatches in the Marrakech High Atlas. Sites of late-lying snow and ice patches earlier in the Holocene, including the 20th Century and the Little Ice Age, are likely to be much more widespread. This list is not exhaustive but highlights the most prominent and repeating late-lying snow and ice patches based on the most recent observations. No glaciers survive today in the Marrakech High Atlas

literature (Brown 1966; Smith 2004; Clark 2012). A list of historical observations and sources is provided in Table 1 .

\section{Dating programme}

The succession of Pleistocene moraines in the High Atlas has been dated using ${ }^{10} \mathrm{Be}$ and ${ }^{36} \mathrm{Cl}$ exposure dating (Hughes et al. 2018). A new ${ }^{10} \mathrm{Be}$ and ${ }^{36} \mathrm{Cl}$ dating programme is underway with a focus on the Late-glacial and Holocene moraines that are present in the highest cirques. These cirque-valleys include the Azzaden valley (Figs. 1 and 2), which was mapped in detail by Hannah et al. 2017 but remains undated. This valley is targeted because it contains the last longest-lying snow in the High Atlas the Tazaghart Névé Permanent. Hannah et al. (2017) hypothesised that moraines immediately in front of the Névé Permanent date to the Little Ice Age whilst the next set of moraines 


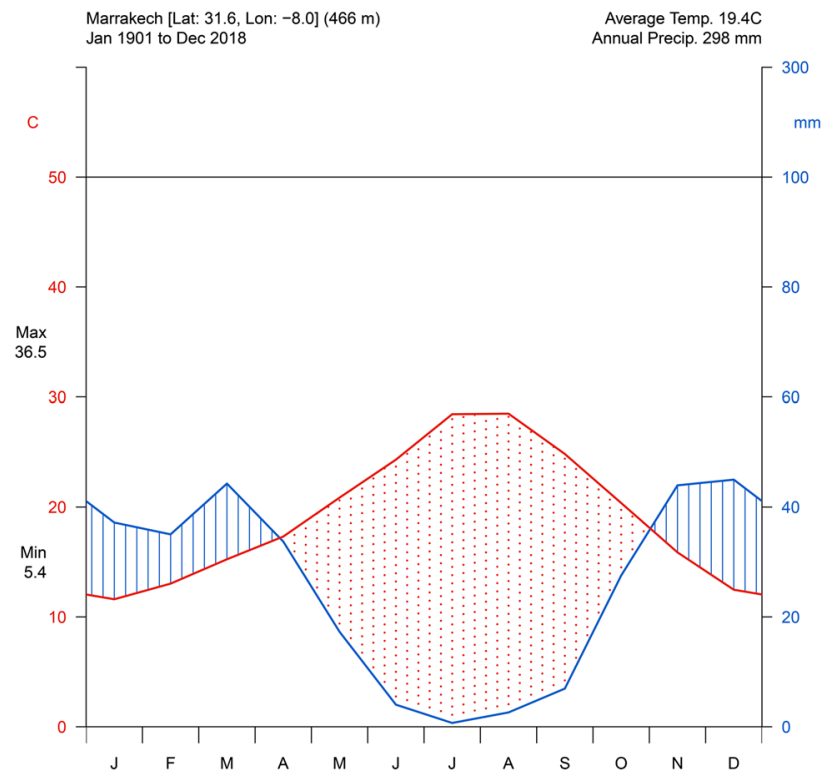

Fig. 3 A Walter and Lieth (1967) diagram of the climate of Marrakech. Data from CRU TS v4.03 (Harris et al. 2014) for the period 1901-2018

down-valley date correlate with Late-glacial moraines dated in neighbouring valleys (Hughes et al. 2018). Cirque moraines in selected areas of Marrakech High Atlas that are known to contain late-lying snow (Fig. 2) will also be the focus of further dating to help constrain the Late-glacial and Holocene sequence in the High Atlas. Current dating results suggest the presence of Younger Dryas moraines in some cirques (Hughes et al. 2018), although the Late-glacial, and potentially Holocene, moraine succession in the High Atlas requires further investigation and is the focus of on-going research.

Relative age dating can also be achieved by quantifying the degree of soil development on moraine surfaces. Soil weathering was quantified using the Harden soil profile development index (Harden 1982). This approach has been successfully employed in a range of contexts in the Mediterranean region to develop a relative-age framework for Pleistocene and Holocene landforms (e.g. Hughes et al. 2006; Adamson et al. 2014). In the Marrakech High Atlas, soil weathering has been quantified on the moraine sequence in the Azzaden valley, the site of the Tazaghart Névé Permanent (Hannah et al. 2017).

\section{Climate records}

Daily climate records (1953-2014) for Marrakech Menara Airport were obtained from the National Oceanographic Data Center (NOAA 2020). Whilst gaps exist in the first two decades of this dataset, the daily record is almost unbroken from 1973 to present for temperature, although with a gap 1998-2002 for winter precipitation. A gridded timeseries dataset at $0.5^{\circ}$ resolution for the period 1901-2018 is also available from the University of East Anglia Climate Research Unit (Harris et al. 2014), the most recent version, released 15 May 2019 (CRU TS v. 4.03). Shorter-term recent local climate data is also available from climate stations in the Marrakech High Atlas. Several meteorological stations have been set up in the Rheraya catchment since 2003, including two high-elevation stations at Oukaimeden $\left(31.180^{\circ} \mathrm{N},-7.865^{\circ} \mathrm{W}, 3,230 \mathrm{~m}\right)$ and Neltner $\left(31.064^{\circ} \mathrm{N}\right.$, $-7.938^{\circ} \mathrm{W}, 3,207 \mathrm{~m}$ ) (sites are described in Baba et al. 2019).

\section{Glacier-climate modelling}

Glacier-climate modelling has been undertaken for Pleistocene glaciers by Hannah et al. (2017) and Hughes et al. (2020). Modern conditions have also been modelled by Hannah et al. (2017) and Hughes (2018). These papers utilised simple degree-day modelling to provide preliminary assessments of the potential melt in the Marrakech High Atlas both in the past and today. The efficacy of degree-day and energy balance approaches for snow runoff modelling have also been examined comparing meteorological data and observed snow ablation the Marrakech High Atlas by Boudhar et al. (2016) and Baba et al. (2019). In this review, we assess the problems and prospects for modelling ablation on glaciers and snow in this region.

\section{Preliminary results}

\section{Geomorphological evidence for recent glacier activity}

Cirque moraines in the Marrakech High Atlas have been dated to the Younger Dryas with a mean age of $12.3 \pm 0.9 \mathrm{ka}$ (Hughes et al. 2018). These last Pleistocene glaciers had a mean equilibrium line altitude of $3213 \mathrm{~m}$. The ELAs were estimated by choosing the accumulation area ratio (AAR) with the lowest standard deviation in a sample of glaciers (Hughes et al. 2020). In several valleys, there are moraines and pronival ramparts above this altitude. These may be related to deglaciation of the last Pleistocene glaciers or may represent glaciers present in the Late Holocene, during the Little Ice Age for example. In the case of the latter, these should correspond to sites where snow survives the longest today. At least 25 sites have been identified that hold the longest-surviving snow in the Marrakech High Atlas (Fig. 2; Table 2). This is a minimum number as there are sometimes multiple snowpatches in the same area. However, four sites have been identified as the longest surviving snowpatches: two below the cliffs of Tazaghart; one in the northern cirque 

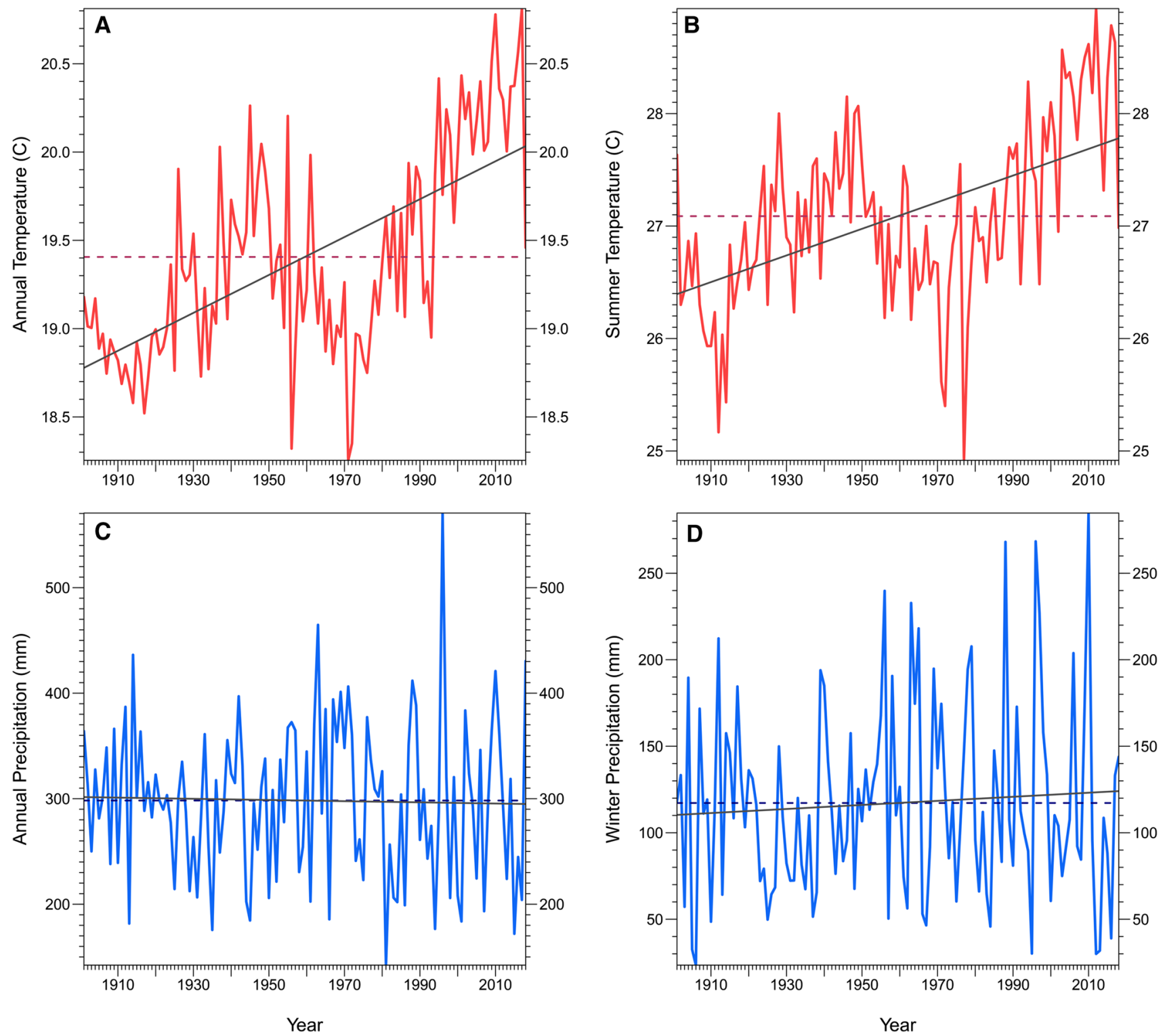

Fig. 4 Climate data for Marrakech from CRU TS v4.03 (Harris et al. 2014) for the period 1901-2018. a Mean annual temperature, (b) Mean summer temperature, (c) Total annual precipitation, (d) Total

winter precipitation. Dotted lines show mean for the entire period, while the dark grey line shows the trend

of Imousser; and one on the NE face of Annrhemer (Fig. 6). These were present in August 2016 when snow was absent at all other sites. All of the sites occupy high elevation positions above $3100 \mathrm{~m}$ in north- and north-east facing hollows of Tazaghart (3980 m), Ras (4083 m), Akioud (4030 m)/ Afella (4043 m), Toubkal (4167 m), Tizi n'Ouanoumss (3664 $\mathrm{m}$ pass and c. $3850 \mathrm{~m}$ peak to the south), Tizi n'Ouagane (3745 m pass), Aksoual (3912 m), Bou Iguenouane (3877 m) Annrhemer (3892 m), and Adrar Meltsene (3597 m) (Fig. 2).

\section{Tazaghart}

The clearest evidence of snow surviving the summer melt season is at the Tazaghart Névé Permanent which is situated at the base of a deep gully on the north face of the Tazaghart Plateau (Fig. 7). This gully and associated perennial snowpatch are often described as the Tazaghart $\mathrm{Cou}$ loir de Neige (e.g. Dresch 1941; Brown 1966; Clark 2012). The feature was described by Hughes (2014) and analysed in detail by Hannah et al. (2017) (Figs. 8 and 9). The current snowpatch is bounded at its base by large moraines which were formed by a former glacier. Hannah et al. (2017) argued that the presence of striated clasts and the 


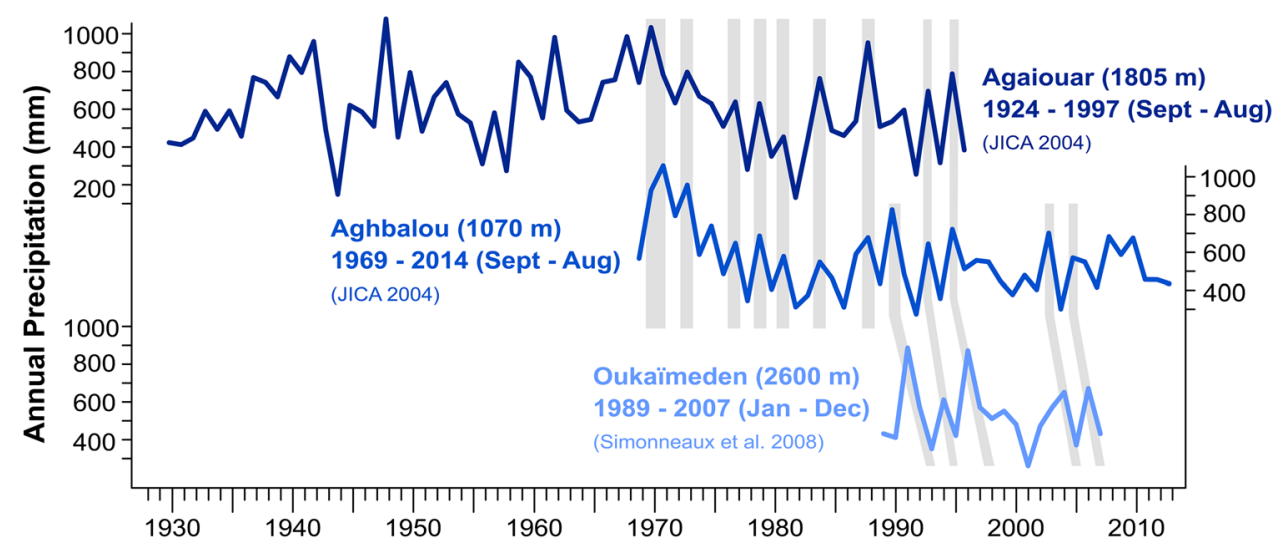

Fig. 5 Mean annual precipitation in the Marrakech High Atlas, showing highly variable inter-annual precipitation recorded at three sites spanning a $1500 \mathrm{~m}$ altitudinal gradient. Although precipitation amounts vary, they show a consistent pattern of precipitation declin- ing in the area since the 1970s: Agaiouar $(31.28,-7.82,1805 \mathrm{~m}$ a.s.1, 1930-1997); Aghbalou (31.32, - 7.75, 1070 m a.s.1, 1969-2014); Oukaimeden (31.20, - 7.85, $2600 \mathrm{~m}$ a.s.1., 1989-2007)

depth of snow accumulation is estimated to be $>30 \mathrm{~m}$. For fresh to settled snow (density $\sim 150$ to $300 \mathrm{~kg} \mathrm{~m}^{-3}$; Boudhar et al. 2016) this would be equivalent to c. $4500-9000 \mathrm{~mm}$ water equivalent (Sturm et al. 2010), although the precise snow depth to water equivalent conversion will be affected by local climate (Hill et al. 2019). A second late-lying snowpatch is also present c. 200 distance to the SE with a lower altitude of $3368 \mathrm{~m}$ in September 2019. As with the main Névé Permanent, this snowpatch lies inside a pair of bouldery moraines. Late-lying snow also occurs close to the pass of Tizi Melloul (3875 m).

Google Earth historical satellite imagery shows that there was little snow at the base of the Tazaghart Couloir de Neige gully in October 2013 with small snowpatches only present at the cliff edge at the top of the gully. However, this imagery is not conclusive because of shade and it is possible that snow/ice was present either under shade or under debris cover. However, the neighbouring second snowpatch was not only absent in 2013 but was also very restricted in clearer imagery in August 2016 with two patches evident 10 and $15 \mathrm{~m}$ in length. These features and the main Névé Permanent are therefore likely to be only semi-permanent since snow is known to disappear completely in some years a suggested by the satellite imagery and confirmed by local guides (Hughes 2018).

Down-valley of Tazaghart Névé Permanent moraines a further three moraine units are present at altitudes of 2000-2200 m, 2600-2850 m and 3000-3200 m (Hannah et al. 2017) (Fig. 8). The moraines in the Azzaden valley down-valley of the Tazaghart Névé Permanent have not yet been dated, although samples ${ }^{10} \mathrm{Be}$ and ${ }^{36} \mathrm{Cl}$ analysis were taken from all four moraines units in September 2019. However, a relative chronology is available based on soil analyses published in Hannah et al. (2017). Soil height of the sediment ridges from the intervening gully the 
Table 1 Selected historical accounts reporting on the presence of snow in the Marrakech High Atlas

\begin{tabular}{|c|c|c|}
\hline Author & Date & Description \\
\hline $\begin{array}{l}\text { Pliny the Elder (Natural History Book V) } \\
\text { (translated in Rackham 1942) }\end{array}$ & $44 \mathrm{AD}$ & $\begin{array}{l}\text { Based on an account by Suetonius Paulinus, the first Roman commander to cross } \\
\text { the Atlas, describes an unknown summit } \\
\text { "The summit is covered with deep snow drifts, even in summer" }\end{array}$ \\
\hline $\begin{array}{l}\text { Lieutenant Washington (The Journal of the } \\
\text { Royal Geographical Society of London) }\end{array}$ & 1831 & $\begin{array}{l}\text { Washington set off in a south-east direction from Marrakech (then "city of } \\
\text { Marocco") towards the High Atlas and described } \\
\text { "Snowy peaks of Atlas beautifully silvered by the meridian sun", "Eternal snows of } \\
\text { Atlas" and a description of the mountain summits around Toubkal } \\
\text { "Yet but once in twenty years had these summits been seen free from snow" }\end{array}$ \\
\hline Society for the Diffusion of Useful Knowledge & 1836 & $\begin{array}{l}\text { On an engraved map of "Barbary Marocco", a mountain known as "Miltsin" is } \\
\text { described as "highest peak, snow capped". Whether this refers to Adrar Meltsene, } \\
\text { Toubkal or another summit is unclear }\end{array}$ \\
\hline Jules Blache (Geographical Review) & 1921 & $\begin{array}{l}\text { In a look at Moroccan life interpreted from aerial photographs and personal } \\
\text { accounts, describes permanent snow } \\
\text { "At elevations over 3,200 m, not far from patches of snow unmelted still in the } \\
\text { August sun" }\end{array}$ \\
\hline Theophile-Jean Delaye & $1936 / 1938$ & $\begin{array}{l}\text { In one of the earliest detailed maps of the High Atlas, to the west of Toubkal, a } \\
\text { snowpatch is marked on the map in a gully on the northern cliffs of Tazaghart. } \\
\text { This snowpatch was marked as the 'Névé Permanent' on later topographic maps } \\
\text { of the Toubkal area (Ministere de l'Agriculture et de la Mise en Valeur Agricole } \\
\text { 1994). However, Delaye (1938, p. 206) noted that there were only a few spots } \\
\text { where snow remains throughout the summer }\end{array}$ \\
\hline Jean Dresch (PhD thesis) & 1941 & $\begin{array}{l}\text { Dresch makes several references to the long-lasting snowpatches (neiges éternelles) } \\
\text { of the Tazaghart and nearby areas (e,g. p. 577) }\end{array}$ \\
\hline $\begin{array}{l}\text { Michael Peyron (Michael Peyron's Berber } \\
\text { website 2010) }\end{array}$ & 1966 & $\begin{array}{l}\text { "Le Couloir de Neige" (snow corridor), which is the Névé Permanent is photo- } \\
\text { graphed and described in June } 1966 \\
\text { "Mais surtout, au creux d'un ravin encaissé, se cache un véritable joyau: le Couloir } \\
\text { de Neige. C'est pratiquement le seul endroit dans le Haut Atlas où, sur près de } \\
500 \text { mètres de dénivelée, l'on retrouve de la neige en toute saison" } \\
\text { Translated to } \\
\text { "But above all, in the hollow of a ravine, hides a real gem: the Couloir de Neige. It } \\
\text { is practically the only place in the High Atlas where, on nearly } 500 \text { m of uneven, } \\
\text { one finds snow in any season" }\end{array}$ \\
\hline Hamish Brown & 1966 & $\begin{array}{l}\text { The survival of snow into summer } 1966 \text { is made even more significant because } \\
\text { of the observations of Hamish Brown who noted that for the period of January- } \\
\text { March } 1966 \text { the lack of snow at the ski resort of Oukaimeden in this "snowless } \\
\text { winter" }\end{array}$ \\
\hline Morocco That Was 1963 to $1972(B \log )$ & $1970 \mathrm{~s}$ & $\begin{array}{l}\text { Photographs taken during the summer by adventurers in the } 1970 \text { s of the "Couloir } \\
\text { de Neige" also show snow is present. The accompanying account describes the } \\
\text { snow corridor: }\end{array}$ \\
\hline Brooks (2017) & & "Once we entered it, we found that the snow turned to ice" \\
\hline
\end{tabular}

profile development index values clearly separate different moraine surfaces and the youngest moraines around the Névé Permanent have almost no soil development. These were moraines correlated with the Little Ice Age in Hughes (2014), which is consistent with the data of Hannah et al. (2017).

\section{Ouanoukrim-Akioud-Afella-Biguinnoussene}

The ridge linking the peaks of Ouanoukrim (4089 m), Akioud (4030 m), Afella (4043 m)-Biguinnoussene $(4002 \mathrm{~m})$ is one of the longest stretches of high ground in the
Marrakech High Atlas and a ridge extends over $5 \mathrm{~km}$ linking these $4000 \mathrm{~m}$ peaks (Fig. 11). Three well-developed cirques are present on the east of this ridge and have well-developed NE-facing cirques and they support late-lying snow and contain well-developed moraines, some of the highest moraines of the Marrakech High Atlas (Fig. 11).

The moraines and cirque thresholds are present in three cirques at altitudes of between 3500 and $3800 \mathrm{~m}$. Late-lying snow occurs below the north face of Ras (4083 m) the northern summit of Ouanoukrim, and a series of boulder ridges are present in the cirque close to the backwall cliffs. However, these are situated $>70 \mathrm{~m}$ from the foot of the backwall 
Table 2 The sites of the latestlying snow and ice patches in the Marrakech High Atlas

\begin{tabular}{|c|c|c|c|c|}
\hline Mountain & Location & $\begin{array}{l}\text { Modern semi- } \\
\text { permanent } \\
\text { snow? }\end{array}$ & $\begin{array}{l}\text { Area }\left(\mathrm{m}^{2}\right)^{\mathrm{a}} \\
12^{\text {th }} \text { August } \\
2016\end{array}$ & $\begin{array}{l}\text { Altitude } \\
\text { (approx. lowest } \\
\text { point) }\end{array}$ \\
\hline Tazaghart & $31.067038,-7.960153$ & $\mathrm{Y}$ & 530 & 3340 \\
\hline Tazaghart & $31.066453,-7.958795$ & $\mathrm{Y}$ & 45 & 3365 \\
\hline Tizi Melloul & $31.057878,-7.955338$ & $\mathrm{~N}$ & - & 3780 \\
\hline Akioud & $31.051082,-7.949472$ & $\mathrm{~N}$ & - & 3750 \\
\hline Akioud/Ras & $31.044450,-7.946357$ & $\mathrm{~N}$ & - & 3780 \\
\hline Biguinnoussene & $31.058467,-7.948173$ & $\mathrm{~N}$ & - & 3700 \\
\hline Toubkal—Irhzer Ikhibi Sud & $31.059232,-7.919729$ & $\mathrm{~N}$ & - & 3850 \\
\hline Toubkal-Irhzer Ikhibi Nord & $31.064008,-7.918308$ & $\mathrm{~N}$ & - & 3800 \\
\hline Toubkal-Imousser North face & $31.067949,-7.913900$ & $\mathrm{Y}$ & 275 & 3740 \\
\hline Toubkal—NE face & $31.058575,-7.904465$ & $\mathrm{~N}$ & - & 3340 \\
\hline Tizi n’Ouanoumss & $31.043516,-7.936636$ & $\mathrm{~N}$ & - & 3690 \\
\hline Tizi-n- Ouanoumss_-Lac d'Ifni & $31.047592,-7.929081$ & $\mathrm{~N}$ & - & 3480 \\
\hline Tizi-n- Ouanoumss_Lac d'Ifni & $31.041998,-7.922214$ & $\mathrm{~N}$ & - & 3100 \\
\hline Tizi-n- Ouanoumss-Lac d'Ifni & $31.037025,-7.922470$ & $\mathrm{~N}$ & - & 3200 \\
\hline Aksoual & $31.126906,-7.864422$ & $\mathrm{~N}$ & - & 3160 \\
\hline Aksoual & $31.125174,-7.859720$ & $\mathrm{~N}$ & - & 3320 \\
\hline Aksoual & $31.123231,-7.852321$ & $\mathrm{~N}$ & - & 3380 \\
\hline Aksoual & $31.129053,-7.841265$ & $\mathrm{~N}$ & - & 3340 \\
\hline Bou Iguenouane N & $31.137518,-7.819467$ & $\mathrm{~N}$ & - & 3430 \\
\hline Bou Iguenouane $\mathrm{N}$ & $31.136172,-7.815875$ & $\mathrm{~N}$ & - & 3590 \\
\hline Bou Iguenouane $\mathrm{N}$ & $31.139390,-7.811951$ & $\mathrm{~N}$ & - & 3730 \\
\hline Bou Iguenouane E & $31.142538,-7.808680$ & $\mathrm{~N}$ & - & 3620 \\
\hline Annrhemer NW & $31.156567,-7.802825$ & $\mathrm{~N}$ & - & 3350 \\
\hline Annrhemer NE & $31.155174,-7.794520$ & $\mathrm{Y}$ & 1800 & 3500 \\
\hline Adrar Meltsene & $31.273489,-7.588511$ & $\mathrm{~N}$ & - & 3140 \\
\hline
\end{tabular}

Sites of permanent snow and ice patches earlier in the Holocene, including the 20th Century and the Little Ice Age, are likely to be much more widespread. This list is not exhaustive but highlights the most prominent and repeating late-lying snow and ice patches based on the most recent observations. No glaciers survive today in the Marrakech High Atlas

${ }^{a}$ Minimum areas since snow in shaded gullies was not visible. Calculated from Google Earth imagery and this is consistent with an interpretation as moraines associated with former niche glaciers rather than pronival/ protalus ramparts (Ballantyne and Benn 1994). Similar moraines are present in the NE cirques of Akioud and Biguinnoussene. The latter site supports snow which is fed by a deep gully, similar to that seen at other sites, such as the Tazaghart cliffs. However, unlike at Tazaghart, snow rarely survives the summer in the NE Biguinnoussene cirque, nor in the Akioud and Ras cirques.

\section{Tizi n'ouagane}

The Tizi n'Ouagane is a $3745 \mathrm{~m}$ high pass between Ouanoukrim (4089 m) and a c. $3850 \mathrm{~m}$ peak to the south of Tizi n'Ouanoumss. The northern side of the Tizi n'Ouagane pass supports several late-lying snowpatches which have been observed to hold snow into August. However, snow is not permanent and was absent in August 2016.

\section{Toubkal}

At least four sites of late-lying snow have been observed in the highest cirques of the High Atlas near the summit of Mount Toubkal (4167 m). Only one of these is likely to be perennial, at the base of a gully on the north-facing cliffs below the subsidiary summit of Imousser (4010 m) (Fig. 11). Here, the snow has been observed surviving summer and the site is very similar to the Névé Permanent below Tazaghart with snow occupying the base of a deeply incised north-facing gully (Fig. 7). In October 2013 the Imousser snowpatch covered an area of $178 \mathrm{~m}^{2}$ with smaller patches also present in the gully above. In contrast, as noted earlier, at the same time no snow was visible at the Névé Permanent below Tazaghart or in any other part of the Marrakech High Atlas at this time. Two other sites include the NW and $\mathrm{W}$ cirques of Toubkal, Irhzer Ikhibi Nord and Irhzer Ikhibi Sud (Fig. 11). However, no snow was observed in the Irhzher Ikhibi Nord 
and Sud in August 1994, July 2007 and September 2017. The situation in the intervening years is unknown. A fourth site is present below the NE cliffs of Toubkal where snow occasionally survives the summer in a deep ravine at the base of the cliffs at c. 3400-3600 m.

Permanently frozen ground (permafrost) is likely to be present in the cirques of Toubkal. At an altitude of $3815 \mathrm{~m}$ in the cirque of Irzher Ikhibi Sud (Fig. 11), Vieira et al. (2017) found that over the period 2015-2016 ground surface temperatures were below $0{ }^{\circ} \mathrm{C}$ for the 6 months of the year from October to March, inclusive. Ground surface temperatures varied from -4.5 to $-6{ }^{\circ} \mathrm{C}$ from December to March, under a continuous snow cover and are interpreted as a strong indicator of the probable presence of permafrost in the highest parts of the Toubkal Massif. Chardon and Riser (1981) suggested that an active rock glacier occurs close to this site, although Vieira et al. (2017) did not support this interpretation because there is no steep front and no clearly defined debris body. However, Vieira et al. (2017) did identify small lobate forms and arcuate ramparts in the talus, possibly indicating active periglacial dynamics, either by solifluction or permafrost creep.

The last glaciers of Toubkal are most likely to have been located at the sites of late-lying snow and permafrost described above. The clearest evidence of this is at the Imousser site where moraines are present in front of the current perennial snowpatch (Fig. 11). The evidence of recent glacier activity at the other sites is less obvious with no clear moraines in the immediate cirque floor area downslope of the snowpatches and permafrost features. However, moraines are clear further (1-2 km) down-valley, although these were formed by substantial cirque glaciers $\left(>1 \mathrm{~km}^{2}\right)$ that were similar, in terms of size and altitude, to Late Pleistocene glaciers (cf. Hughes et al. 2018, 2020).

\section{Tizi n'ouanoumss and Lac d'Ifni}

Immediately south of Toubkal, a valley contains the only lake in the massif, Lac d'Ifni (Fig. 1). The pass of Tizi n'Ouanoumss $(3664 \mathrm{~m})$ lies at the head of this valley between Toubkal (4167 m) and Igger n'Abdeli (c. $3815 \mathrm{~m}$ ) (Fig. 11). The lake is dammed by a huge rock slope failure debris (Hughes et al. 2014). This barrage was linked to glacial activity by Célérier and Charton (1923) who suggested the rock slope failure occurred upon glacier retreat. However, the evidence for Pleistocene moraines in this valley is elusive because of the vastness of the rock slope failure debris and also because thick accumulations of fluvial gravels have accumulated in the valley floor up-valley of the lake. For this reason, a question mark was left regarding the glaciation of this valley in Hughes et al. (2018)(Fig. 1). However, Dumont et al. (1973, p. 42) claimed that the lake is glacier-fed in modern times with a glacier "filling up the valley between the Jebel Toubkal and the Tizi n' Ouauoumns [sic]. In Summer, the glacier tongue regresses to about $3 \mathrm{~km}$ from the lake, and its meltwaters form a small river, the Asif n'Moursaine flowing down to the lake". However, in August 1994 no snow was observed in this valley, nor in the area near the head of the pass Tizi n'Ouanoumss, although historical satellite imagery confirms that snow does survive until July in three long and deep NE-facing gullies to the south of the pass, at altitudes as low as $3100 \mathrm{~m}$. In 2019, local guides confirmed the common occurrence of late-lying snow in this area. The "glacier" described by Dumont et al. (1973) is very likely to have been a late-lying snowpatch sustained by avalanching snow from these gullies and the surrounding cliffs rather than a true glacier. Nevertheless, the observations of Dumont et al. (1973) do suggest that snow conditions were much more extensive in the early 1970 s than in the last few decades. It also suggests that this valley must have been glaciated in the Pleistocene.

\section{Aksoual and Bou Iguenouane}

Little Ice Age moraine and pronival ramparts ridges are present in the northern valleys and cirques of Aksoual (3912 m) and Bou Iguenouane $(3877 \mathrm{~m})$ in the Imenane Valley (Fig. 12). In most valleys and cirques three moraine units are present, with the upper unit dating to the Late-glacial. For example, in the Irhzer Likemt valley moraines between 2975

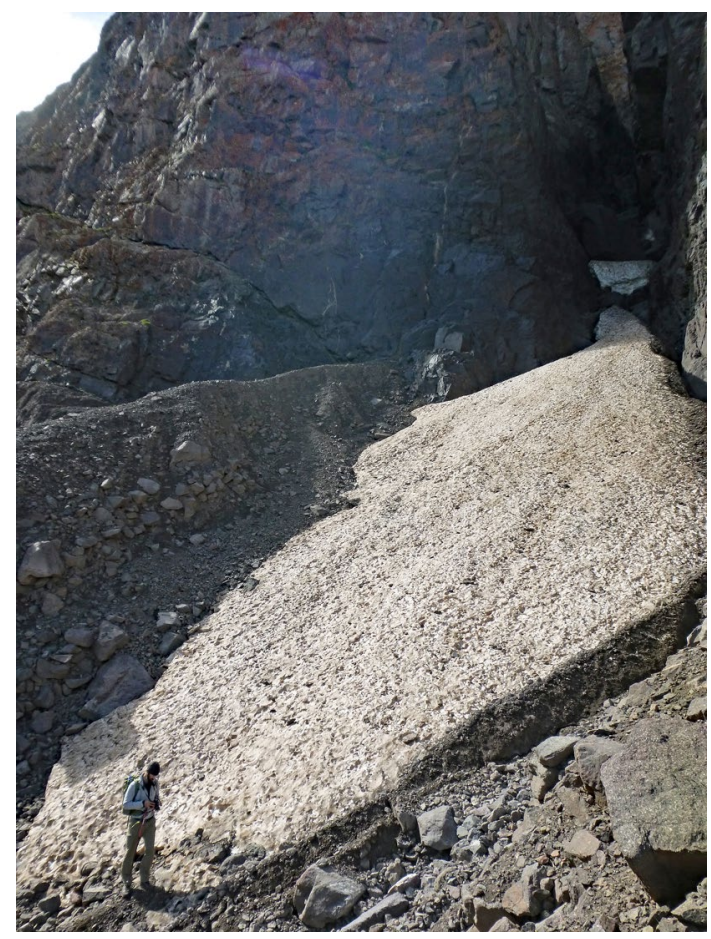

Fig. 6 Photograph of the Tazaghart Névé Permanent in September 2019 (photograph by Philip Hughes) 
Fig. 7 Google Earth satellite images at the same scale and at the same time (4th July, 2019) showing the four sites in the High Atlas where snow lies the longest: Tazaghart (2 sites); Imousser, and; Annrhemer
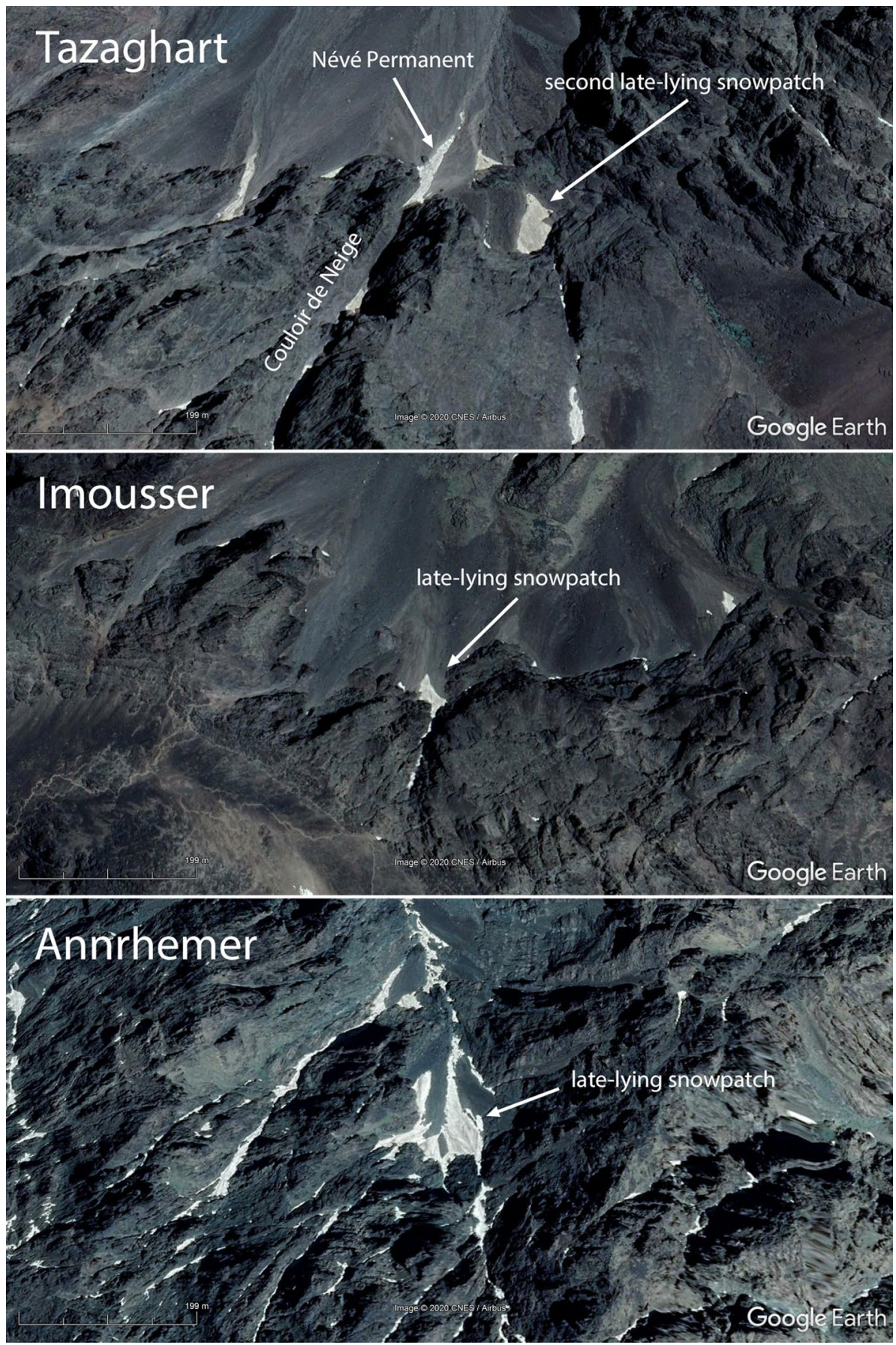

and $3035 \mathrm{~m}$ have yielded ${ }^{10} \mathrm{Be}$ exposure ages of $13.7 \pm 0.8$ and $12.1 \pm 0.8 \mathrm{ka}$ and were interpreted as Younger Dryas in age by Hughes et al. (2018). However, the age of the unit three moraines (Fig. 12) may be diachronous with some dating to the Late-glacial and some potentially being younger. Furthermore, a fourth moraine/pronival rampart unit is present at altitudes of 3300-3600 m (not marked in Fig. 12). These are situated close to the backwall or in deeply incised valleys that currently support late-lying snow and whilst some of these may present Late-glacial recessional moraines, it is possible that some of these highest moraine/ pronival units are Holocene in age. On Bou Iguenouane a high-level cirque is also present on the eastern slopes and a series of moraines enclose some of the latest-lying snow of this area. Snow was absent from all areas of Aksoual and Bou Iguenouane in October 2013.

On the NW face of Aksoual the northern cliffs of the ridge of Azrou n'Tamadôt represent one of the largest cliff faces in the Atlas Mountains rising $1500 \mathrm{~m}$ in c. $2 \mathrm{~km}$. A potential fourth moraine unit (not marked in Fig. 12) is 
Fig. 8 Glacial geomorphological map of the Azzaden Valley leading up to the Tazaghart Névé Permanent. The soil profile and clast analysis data are reported in Hannah et al. (2017). Figure adapted from Hannah et al. (2017)

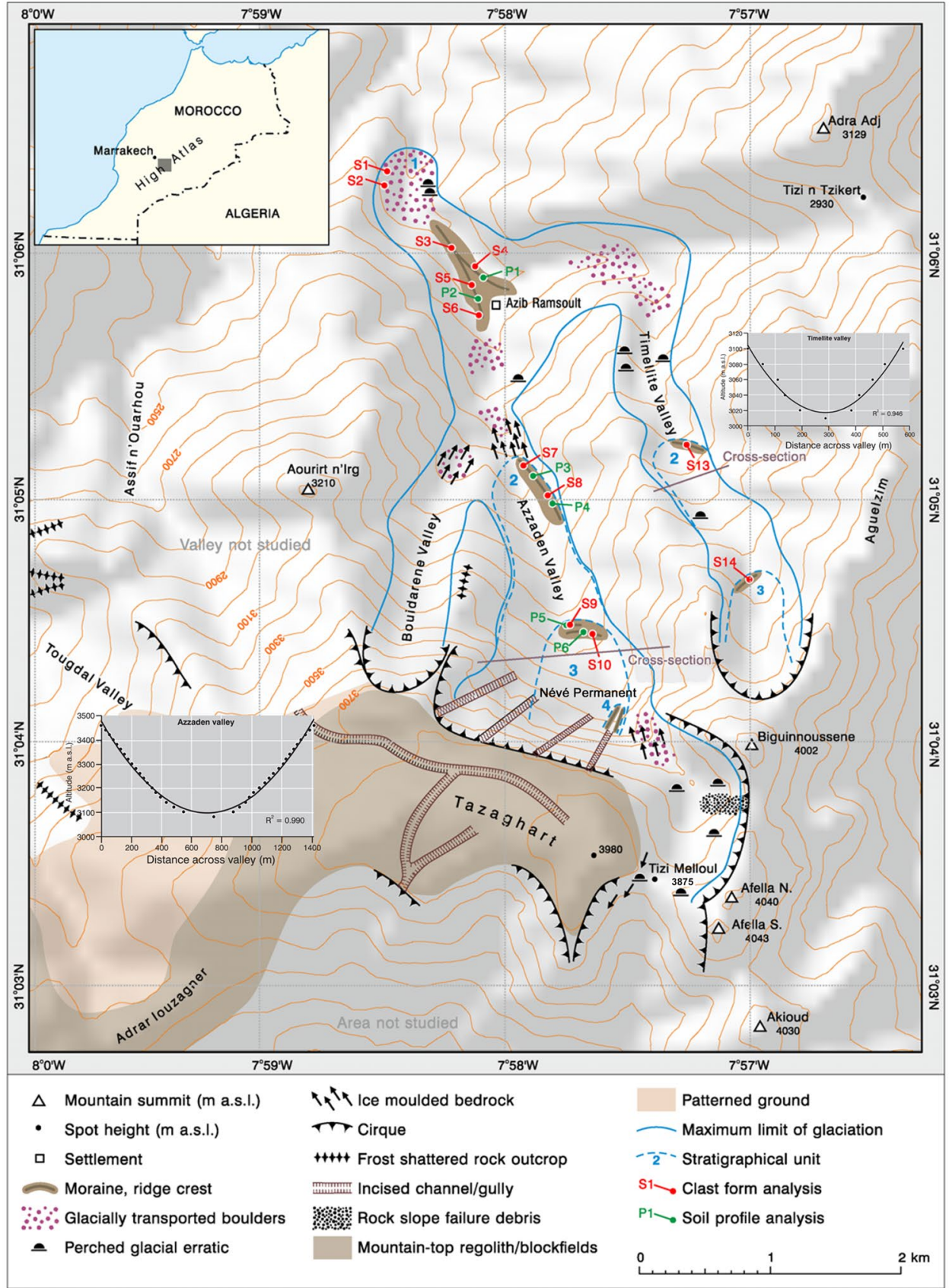

also present in this Assif n'Imserdane valley close to the backwall below the steepest sections of the cliffs. Some of these moraines are situated at much lower altitudes than at other sites, although the moraine fronts range from 2400-3000 m, which is likely to be explained by local topoclimatic controls, especially shading and avalanching snow. This western side of this valley has been affected by rock slope failure at c. $4.5 \mathrm{ka}$ and Pleistocene moraines were widely disturbed at this time, resetting their exposure ages (Hughes et al. 2014). Nevertheless, any later glaciation that has occurred in the Late Holocene may be detectable using exposure dating. If a niche glacier was present at this site in the Late Holocene, then it could have only existed under the influence of very strong local topoclimatic controls, and possibly debris cover. This is known to have been the case for the Pleistocene Late-glacial in the Marrakech High Atlas when equilibrium line altitudes of glaciers varied by $>1000 \mathrm{~m}$ (Hughes et al. 2020). Alternatively, these moraines may be Late Pleistocene in age since some cirque moraines elsewhere at the 


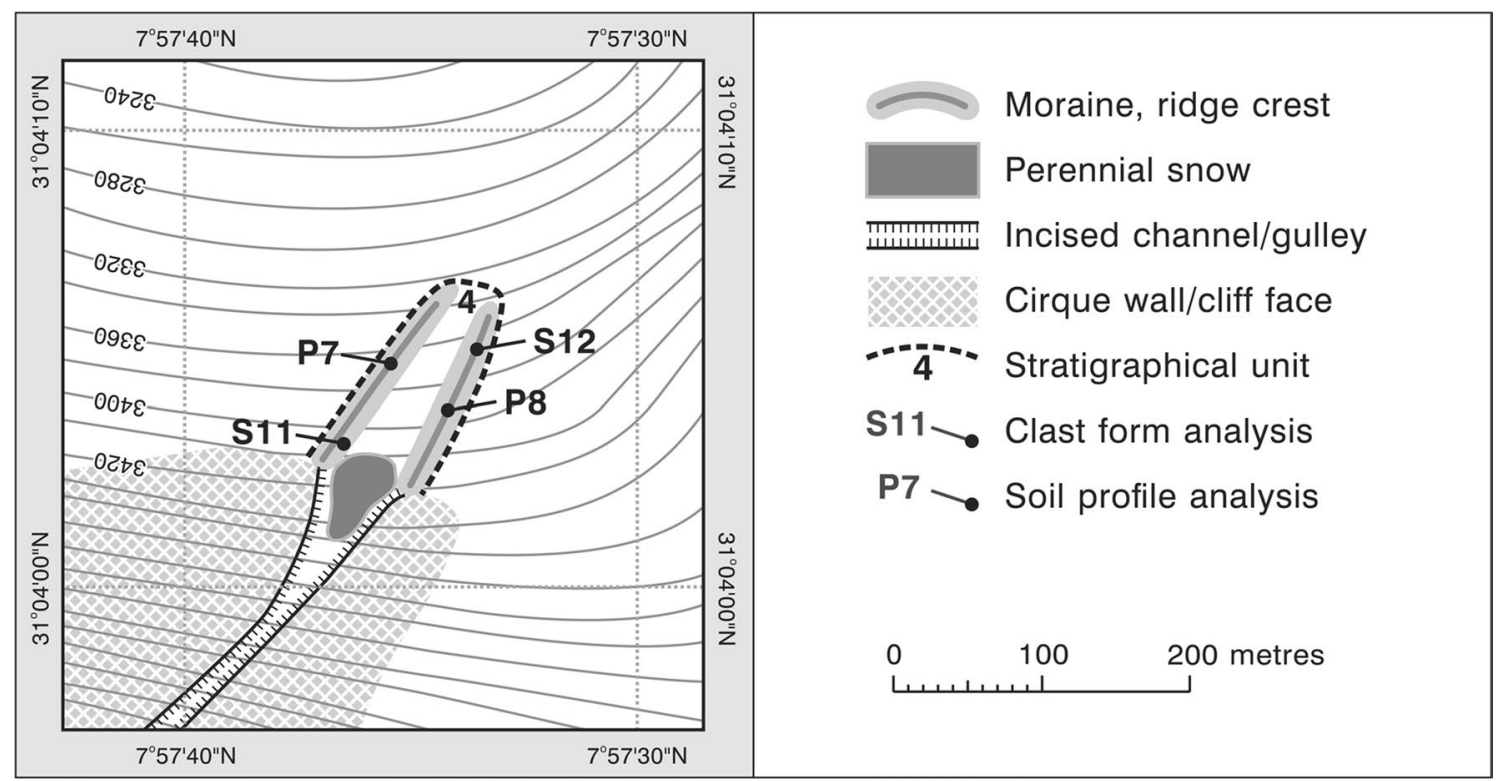

Fig. 9 Geomorphological map of the Tazaghart Névé Permanent (site 1 in Fig. 2; stratigraphical unit 4 in Fig. 8) and clast data from the sediment ridges bounding this feature. The clast form analysis from

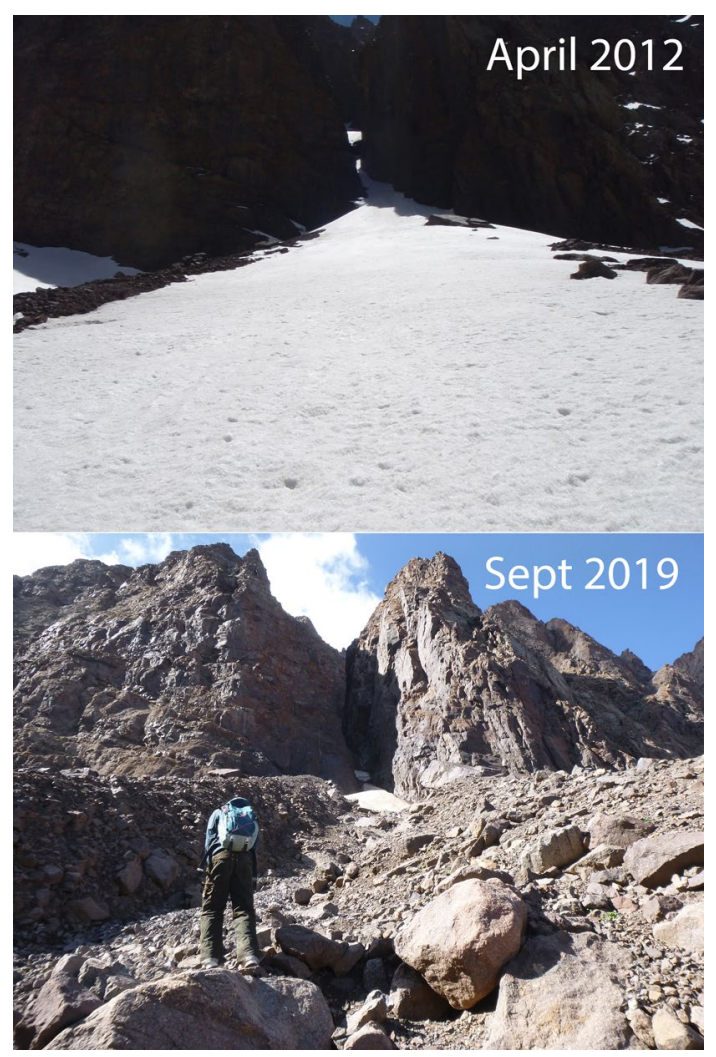

Fig. 10 Snow filled the entire hollow between moraine ridges below the Tazaghart Névé Permanent in April 2012 (photograph by George Hannah). The depth from the moraine crests to the base of the hollow is up to $30 \mathrm{~m}$ in places. The bottom photograph shows the same location in September 2019 (photograph by Philip Hughes) two sites on each ridge shows that clasts are prediminantly blocky, subrounded and with some clasts displaying striae. No soil development was apparent on the surface of either sediment ridge (from Hannah et al. 2017)

same altitude of the Assif n'Imserdane have been dated with ${ }^{10} \mathrm{Be}$ to the Late-glacial (Hughes et al. 2018).

\section{Annrhemer}

Annrhemer (3892 m) is just over $2 \mathrm{~km}$ NE of Bou Iguenouane (Fig. 1) and supports late-lying snow in two cirques on its north face. The largest accumulation and longest-lying snow occur on the eastern cirque face at c. $3600 \mathrm{~m}$ (Fig. 7). Snow survived into August in 2016. However, snow was absent in October 2013. This site is significant because it represents the largest body of late-lying snow in the Marrakech High Atlas with snow covering an area of c. $1800 \mathrm{~m}^{2}$ in August 2016, compared to $530 \mathrm{~m}^{2}$ at the Tazaghart Névé Permanent (Table 2).

\section{Adrar Meltsene}

An outlier of the main Marrakech High Atlas, Adrar Meltsene (3597 m) (see Fig. 2) supports late-lying snowpatches into July on its northern face. This snow is present down to an altitude of c. $3140 \mathrm{~m}$ at the base of a shallow cirque and above a deeply incised gully at the base of which a series of moraines are present. The Adrar Meltsene snow is typical of other marginal sites in the wider High Atlas and similar late-lying snowpatches are potentially present on any mountains that reach $>3500 \mathrm{~m}$ and where cirque floors and cliff bases are $>3100-3200 \mathrm{~m}$. Anecdotal evidence from local shepherds suggests that year-round snowpatches were 


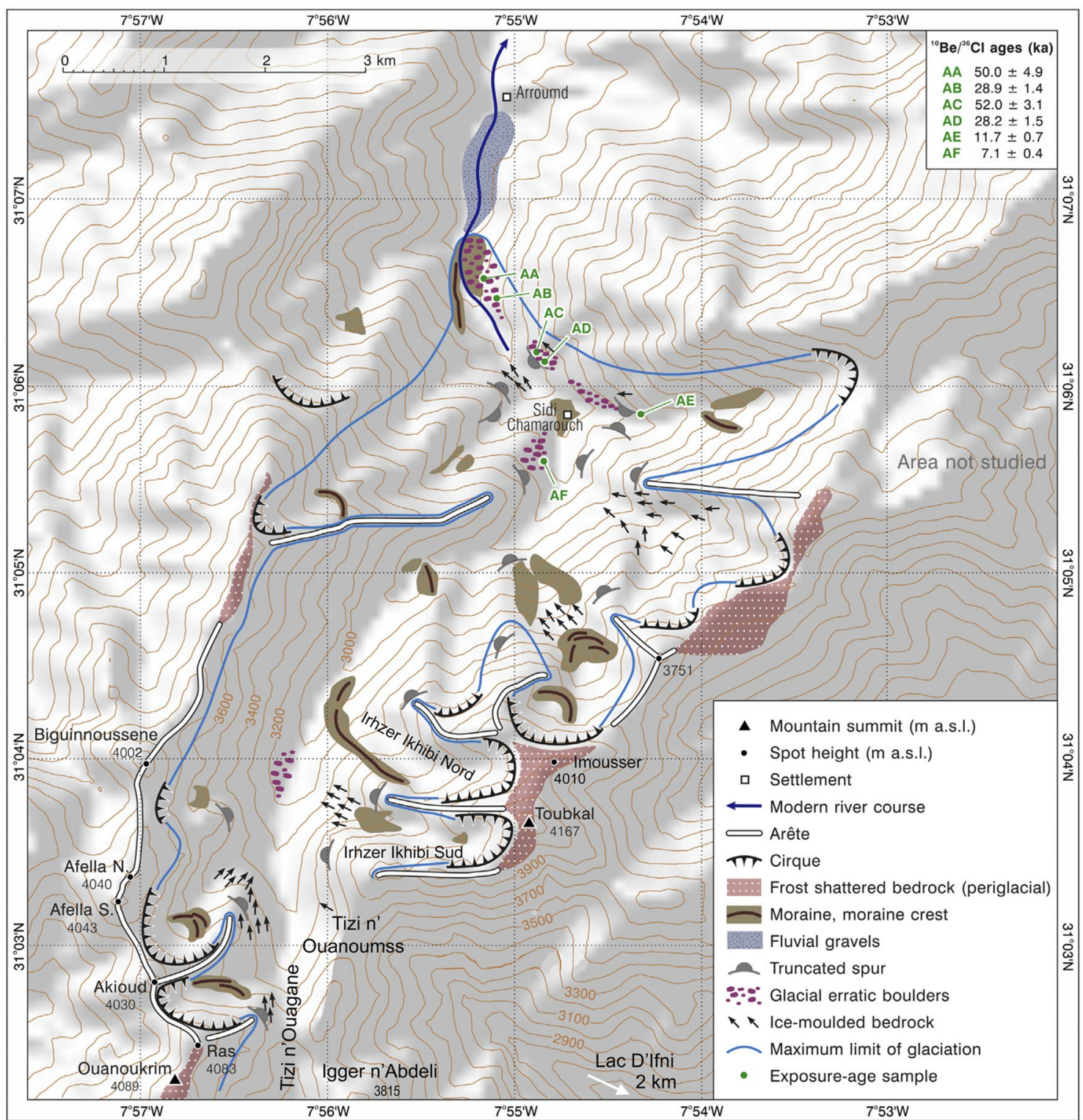

Fig. 11 Glacial geomorphological map of the central Toubkal area. Not all moraines are shown, especially smaller features in the highest cirques. The map is from Hughes et al. (2018) who focused on the Late Pleistocene history of the region. The moraines have not been

more common in the era of their grandparents (early/mid twentieth century).

\section{Historical accounts}

Throughout time, explorers and travellers have documented the natural landscape as they found it. In the High Atlas, descriptions of snow and ice that is present year-round can be found in various literature and early photographs, the earliest dating back to the Roman period. Table 1 summarises these descriptions. separated into morphostratigraphical units, unlike for the Aksoual area (see Fig. 12) because of the lack of geochronological control for this area

Although personal accounts or anecdotes should be treated with caution, the numerous descriptions from people who explored the mountains would suggest that yearround or permanent snow has been a feature of the High Atlas in historical times. Snow can fall in the High Atlas as early as September through to June (Peyron 1980). Joseph Thomson climbed to Tizi Likemt in September 1888 and noted that "Even at that late time of year we found ourselves among wreaths of snow" (Thomson 1889, p. 462). More recently, Dee and Guigan (1993) noted that "Snow fell in the upper part of the catchment in mid-September 1990". 


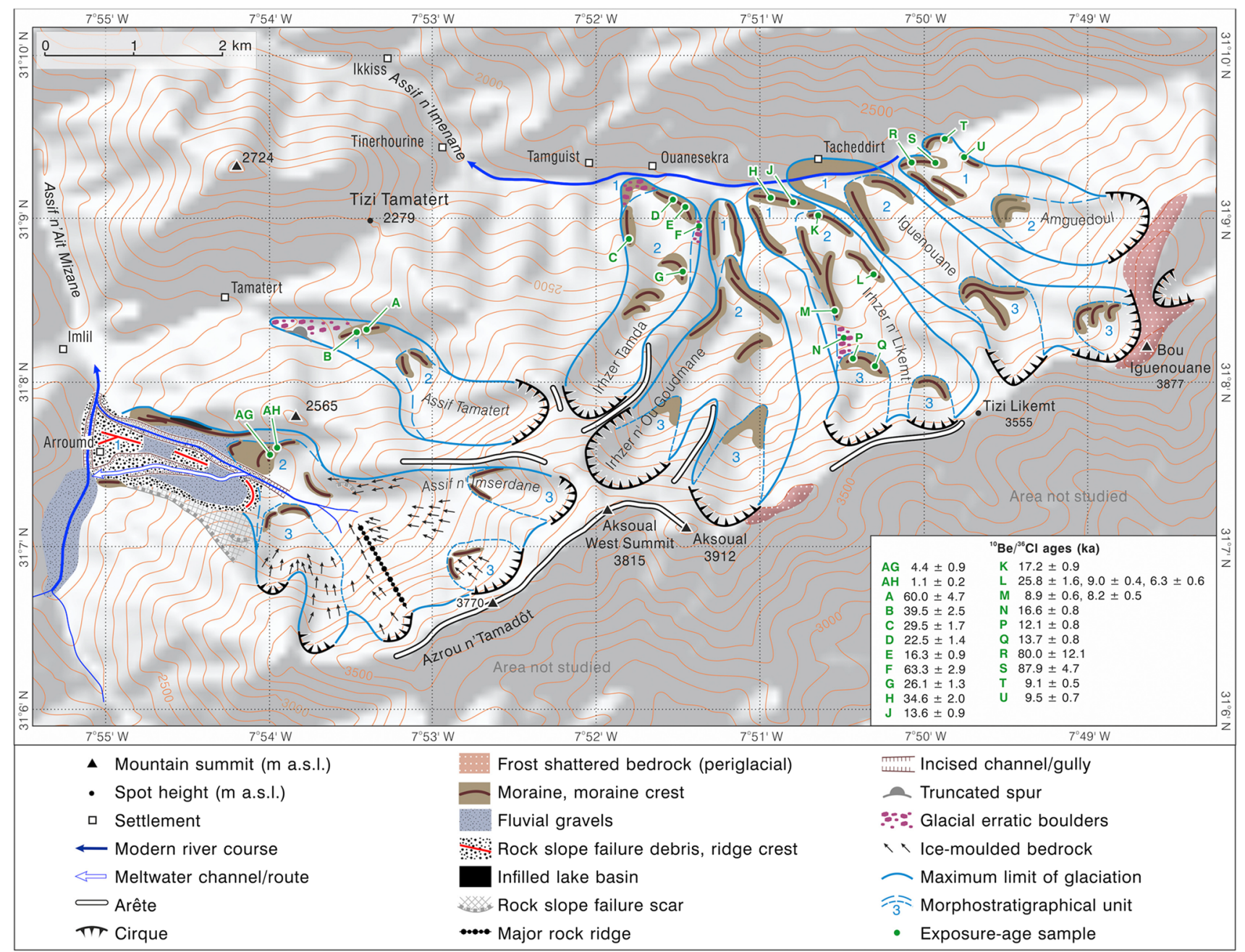

Fig. 12 Glacial geomorphological map of the Aksoual area, c. 5-10 km NE of Toubkal. The moraines were dated using cosmogenic exposure dating $\left({ }^{10} \mathrm{Be}\right.$ and $\left.{ }^{36} \mathrm{Cl}\right)$ and subdivided into morphostratigraphical units by Hughes et al (2018). Unit 3 moraines were thought to be Pleistocene Late-glacial in age based on correlations with some

Thus, the snow season is sometimes potentially ten months long and thus the survival of snow and ice throughout July and August in some years is not inconceivable. Equally, even winter snow is prone to a very fickle climate and in some years snow cover is limited even in January. This is highlighted by the large variations in winter precipitation (Fig. 4). Nevertheless, in niche settings influenced strongly by shading and avalanching snow, such as below gullies in steep NE-facing cliffs, snowpatches remain very resilient. This evidence indicates that in such microclimate settings the snowpatches appear almost decoupled from the regional climate. Under slightly cooler temperatures during the Little Ice Age it is therefore easy to imagine the presence of small niche glaciers, as is observed today in other parts of the Mediterranean mountains (Hughes and Woodward 2009; Grunewald and Scheithauer 2010). dated moraines (e.g. sites $\mathrm{P}$ and $\mathrm{Q}$ in the Irhzer n'Likemt). However, some Unit 3 moraines may be younger and there is evidence that younger moraines and pronival ramparts are present inside of these unit 3 moraines, close to cirque backwalls and associated with latelying snow (see Table 2 for locations). From Hughes et al. (2018)

\section{Climate data since 1901}

The climate changes at Marrakech since 1901 are illustrated in Fig. 4, derived using the gridded climatology (Harris et al. 2014). As is common throughout Morocco, two periods of cooling are evident at Marrakech. The first occurs at the beginning of the twentieth century until 1917, and the second period occurring between 1940 and 1972. These multidecadal changes are strongly correlated with the slowchanging component of Atlantic Ocean temperature variability known as the Atlantic Multidecadal Oscillation (AMO) (Kerr 2000). However, the general trend also shows that mean annual temperatures have increased since 1901, with a large increasing trend since the 1970s over which period summer temperatures have increased by $>2{ }^{\circ} \mathrm{C}$ (Fig. 4a). Summer temperature trends (Fig. 4 b) largely follow the 
same pattern as annual temperatures, with a mean summer temperature of $27.1^{\circ} \mathrm{C}$. Annual precipitation at Marrakech is a highly variable year on year (Fig. 4c), hence the annual trend suggests little change in precipitation since 1901. Winter precipitation is also highly variable, varying by $>400 \%$ between some years (Fig. 4d). Winter precipitation is higher in the mountains but is also very variable. For example, winter precipitation totals of c. $160 \mathrm{~mm}$ and $1080 \mathrm{~mm}$ were recorded at Agaiouar (1805 m) in 1944 and 1948, respectively (Fig. 5).

\section{Climate modelling}

Hannah et al. (2017) calculated the theoretical modern melt totals for the Tazaghart Névé Permanent based on extrapolations of observed monthly mean temperature data from the Marrakech Menara meteorological station. At $3400 \mathrm{~m}$ the melt was estimated to be $5366 \mathrm{~mm}$ when using degree-day factor of $4.1 \mathrm{~mm}^{\circ} \mathrm{C}^{-1} \mathrm{day}^{-1}$ (Braithwaite 2008). At the Neltner Refuge (Toubkal refuge), $2.17 \mathrm{~km}$ from the Névé Perma$n e n t$, the mean annual precipitation for the 14-year period $1949 / 50-1963 / 64$ was $837.3 \mathrm{~mm}$ at an altitude of $3200 \mathrm{~m}$ (Messerli 1967). Thus, the amount of snow accumulation required to balance melting is potentially more than five or six times that which falls directly from precipitation as snow. Hughes (2018) cautioned that the effects of sublimation considerably reduces the energy available for melting, potentially meaning a lower degree-day factor for snow (Lang and Braun 1990; Hock 2003). Furthermore, the energy used in sublimation could also have the effect of significantly lowering surface temperatures over snowpatches compared with the surrounding air. Lopez-Moreno et al. (2017) found that latent energy losses are very high in the Atlas Mountains, where sublimation represents $25 \%$ of total snow accumulation. Based on this characteristic Lopez-Moreno et al. (2017), predicted that the Atlas Mountains snowpack will have relatively low sensitivity to climate warming.

The effects of sublimation on snow ablation in the Atlas Mountains have been recognised in several papers. Schulz and de Jong (2004) described the occurrence of snow penitents in the Toubkal and M'Goun Massifs, respectively. These ablation features are characteristic of sublimation processes (Lliboutry 1954). This effect means that the role of air temperature on snow ablation is reduced and in the M'goun Massif of the High Atlas up to $44 \%$ of snow ablation is attributed to sublimation in typical winters under dry and cold conditions (Schulz and de Jong 2004). However, in their study of snow pack ablation at Oukaimeden (Figs. 1 and 2) Boudhar et al. (2016) found that net radiation was found to dominate the surface energy balance and is the major energy source for snowmelt, and reported good performance of simple index models based on either radiation or temperature. Conversely, based on the point-scale modelling studies for the study area, Baba et al. (2019) advocated that a distributed energy balance approach is preferable to degree-day methods because they argued the latter does not explicitly include radiation and neglects sublimation.

\section{Discussion and future research}

\section{Comparisons with other Mediterranean mountains}

The evidence of late-lying snow and potentially small glaciers in the High Atlas in the last few hundred years is matched by evidence from other areas of the Mediterranean. Late-lying snow is common to many Mediterranean mountains and nivation is an important process in the highest parts of the mountains (Palacios et al. 2003). However, true glaciers are comparatively rare although today glaciers are present in the Pyrenees (Spain), the Apennines (Italy), the Julian Alps (Slovenia), Dinaric Alps (Montenegro and Albania), the Pirin Mountains (Bulgaria) and in several mountain areas of Turkey (see reviews by Hughes and Woodward 2009 and Grunewald and Scheithauer 2010). The largest glaciers are in Turkey where substantial ice caps and valley glaciers exist (Sarıkaya and Tekeli 2014; Azzioni et al. 2017), although in southern Europe they are mostly small niche glaciers that exist in cirques with strong topoclimatic controls on mass balance. Many are now marginal between ice patches and true dynamic glaciers (e.g. Serrano et al. 2011). In all areas, glaciers were more extensive at the end of the Little Ice Age, 100-200 years ago (Hughes 2014). These glaciers have since experienced overall retreat through the 20th Century. In some areas, glaciers have recently disappeared or split into multiple smaller ice patches. In the case of the Corral de Veleta site in the Sierra Nevada, southern Spain, a glacier present in the 1920s was the southernmost in Europe. Today the glacier has gone and only a small patch of permafrost survives (Gomez-Ortiz et al. 2009; Oliva et al. 2020). In Albania, some small glaciers present a decade ago (Hughes 2009) were reduced to static snowpatches within four to five years whereas others remained active (Gachev et al. 2016). In contrast, in Montenegro, the Debeli Namet glacier has been resilient despite a trend to warmer summers and still survives (Hughes 2007, 2008; Djurović 2013). These glaciers expand and contract dramatically relative to their overall size and this is because of the rapid response of small glaciers to changes in mass balance. In some years, these small glaciers experience positive or negative mass balance over their entire surface because of their small size and limited altitudinal distribution. Thus, the concept of an equilibrium line altitude does not apply easily to these types of small glaciers. 


\section{Climatic controls on glacier and snowpatch survival}

Hot summers can cause proportionally large changes in glacier area on small glaciers (e.g. Hughes 2008). Nevertheless, strong topoclimatic controls (shading, avalanching and windblown snow) do mean that many small glaciers are resilient to year-on-year climatic variability and are essentially decoupled from the regional climate. Thus, whilst it is true that small glaciers are sensitive to climate change, it is sometimes not the case for very small niche glaciers since their sensitivity is proportional to the scale of the ablation or accumulation controls exerted by their topographic setting. This is exemplified in the fact that in 2013 the largest latelying snowpatches in the Marrakech High Atlas disappeared, including the Annrhemer snowpatch and possibly also the Tazaghart Névé Permanent, whereas the usually much smaller snowpatch below Imousser held on and survived.

\section{Holocene glaciers and late-lying snow in the High Atlas}

Based on recent reconstructions of fluctuating Holocene hydroclimate in Morocco (e.g. Fletcher and Zielhofer 2013; Zielhofer et al. 2017a, b), there are several time intervals during which small glaciers and expanded late-lying snow cover may have existed in the High Atlas. These include: The Little Ice Age (c. 1550-1850 or 1300-1950 AD) (Hughes 2014, 2018), The Late Antiquity Little Ice Age (LALIA, c. 536-660 AD) (Büntgen et al. 2016), The $8.2 \mathrm{ka}$ event, and related early Holocene cooling events (Fletcher and Zielhofer 2013; Zielhofer et al. 2017a, b). These episodes are of great interest for regional palaeoclimate and their potential impact on alpine environments and land use by human societies. Specifically, summer melting of expanded glaciers and the wider snowpack would increase summer water supply in the alpine landscape, favouring pastoral activities that underpinned traditional Amazigh (Berber) economy, urbanisation in the Atlas piedmonts (Aghmat, Marrakesh, Ouarzazate), and contact between the mountain and desert societies of North Africa. The detailed interaction of climate and demographic change requires further exploration. For example, climate changes around the LALIA have been posited as a driver of the Umayyad Arab Invasion of North Africa (Büntgen et al. 2016; Fletcher and Hughes 2017).

The persistence of snow through the Holocene has important implications not only for water supply for humans but also for biological refugia and the evolution of cold-adapted flora and fauna. Arctic- and alpine-habitat flora and fauna have a limited spatial range in Morocco because of the southerly latitude. Such species are restricted to the highest altitudes of the Atlas Mountains and this means that these species are especially vulnerable to climate change with alpine, cave and endogean habitats acting as important postglacial refugia (Hernando et al. 1999). For example, Arctic-habitat beetles have been found near the surface next to snowpatches in the Toubkal massif at altitudes as low as $2500 \mathrm{~m}$ (Casale 1988 cited in Hernando et al. 1999). In terms of flora, the Toubkal Massif is home to numerous arctic-alpine plant species. Above altitudes of $3800 \mathrm{~m}$, Ros et al. (2000) termed the habitat as "cryoro-Mediterranean" with the highest concentration of endemic cormophyte species. However, cold-adapted species occur at altitudes below this and Ros et al. (2000) identified numerous boreal- and arctic-alpine bryophytes including the moss Brachythecium collinum in a wet grassland at $3330 \mathrm{~m}$.

\section{Future research questions}

\section{Until when were the last Pleistocene glaciers present in the High Atlas?}

Establishing the ages of the youngest Pleistocene moraines is important to set the context for understanding the state of the cryosphere in the Holocene. The altitudes of these last Pleistocene glaciers and presence or absence of stratigraphically younger moraines up-valley of these glaciers provides an important clue as to the potential for Holocene glaciation. Hughes et al. (2018) provided some evidence that the last glaciers were Younger Dryas in age. However, whilst the cosmogenic exposure ages clearly show a well-defined Late-glacial moraine unit, the ages from two separate valleys ranged from $13.7 \pm 0.8$ to $11.5 \pm 0.7 \mathrm{ka}$. Given that the altitude of the highest Late-glacial moraines dated by Hughes et al. (2018) was at a cirque lip at an altitude of only 2975-3035 m, there is clearly scope for later glacier development in some valleys. The highest cirque-floor altitudes are $>3300 \mathrm{~m}$ and some peaks exceed altitudes of $4000 \mathrm{~m}$. A future priority is therefore to provide more precision on the age of the last Pleistocene glaciers in the High Atlas and to also to delimit the extent of these glaciers.

\section{Is there any evidence of Holocene glacier activity in the High Atlas?}

This paper has described the evidence for late-lying snow in some of the cirques of the High Atlas. However, it still needs to be tested whether these occupy sites bounded by Late Pleistocene or Holocene moraines. Dating and delimiting the extent of the last Pleistocene glaciers will help constrain the potential limits of Holocene glaciers, although any moraines inside of these limits will also need to be dated. Differentiation will also be required between moraines associated with true dynamic glaciers and pronival/protalus ramparts associated with static late-lying snowpatches. Particular focus should be made to dating moraines/ramparts immediately 
down-valley of sites known to support late-lying snow today, such as the Tazaghart Névé Permanent. A key question is whether these moraines are very recent, i.e. Little Ice Age, or represent glaciers from the earlier parts of the Holocene. Very recent moraine formation, such as at the end of the Little Ice Age (100-200 years ago) will yield minimal cosmogenic nuclide concentrations. However, a succession of moraines as young as 580-140 years old have been successfully dated using ${ }^{10} \mathrm{Be}$ in the Alps. This has allowed for Little Ice Age moraine successions to be identified, even from small samples with as little as $7 \mathrm{~g}$ of purified quartz (Schimmelpfennig et al. 2014).

\section{What is the evidence of Holocene environmental changes in the High Atlas and how could this have affected snow and ice mass balance?}

Potential changes in snow and ice mass balance in the High Atlas needs to be understood in the context of climate and wider environmental history of the region, and integrated with high-resolution palaeoclimate records available from lake sediments (e.g. Cheddadi et al. 1998; Rhoujjati et al. 2010; Zielhofer et al. 2017a, b; see below for further references), speleothems (Wassenburg et al. 2013; Brahim et al. 2017; 2019) and tree rings (Esper et al. 2007). However, the climate and wider environmental history of the High Atlas is poorly known compared with other parts of Morocco.

Some of the best records for providing a continuous archive of Holocene environmental change are from lake and marsh sediments. In the Atlas Mountains, most of these records have been obtained in the Middle Atlas, with numerous publications documenting pollen and other proxies for environmental change through the Late Pleistocene and Holocene (e.g. Lamb et al. 1989, 1995, 1999; Lamb and van der Kaars 1995; Barker and Roberts 1994; Cheddadi et al. 1998, 2019; Rhoujjati et al. 2010; Nour el Bait et al. 2014, 2016; Tabel et al. 2016; Campbell et al. 2017; Fletcher et al. 2017). However, equivalent records from the High Atlas are less common. Furthermore, whilst some data from Holocene and Late-glacial lake sequences have been published from the central and eastern High Atlas (e.g. Lamb et al. 1994), very few records exist for the Marrakech High Atlas. The studies that do exist have limited resolution and geochronology and are few in number (e.g. Reille 1976; Bernard and Reille, 1987; Reille and Pons, 1992). Since this early work, no full Holocene (nor Late-glacial) lake sediment records have been published for this region. However, Mid- and Late Holocene environmental records have recently been published from marshes in the area by Ruiz et al. (2015) and Fletcher and Hughes (2017), although no records exist that are comparable to those published in the Middle Atlas.

Work is in progress to provide continuous records of Holocene environmental change from the Marrakech High
Atlas. Sites that have potential include the Yagour Plateau (Fig. 2), where a coring expedition took place in 2019, and at Oukaimeden where lake and marsh sites have yielded several metres of sediment in recent coring investigations. The proximity of these sites $(5-30 \mathrm{~km})$ from the cirques of the Marrakech High Atlas mean that any continuous environmental records will provide useful parasequences to which geomorphological records for late-lying snow and glaciers can be tied (cf. Hughes et al. 2005). Sediments from an infilled basin near Arroumd (Figs. 1 and 12) in the Toubkal Massif were analysed in Fletcher and Hughes (2017), although this sediment sequence spans just the last c. 1500 years and represents a rapid infill event. Only one lake exists in the central Toubkal Massif at Lac d'Ifni (Fig. 1), a lake dammed by landslide deposits of unknown age (Hughes et al. 2014). This lake could have potential to provide a record of Holocene environmental change, although similar mass movement deposits in the area are only mid-Holocene in age (Hughes et al. 2014), and the lake is very deep $(60 \mathrm{~m})$ and has a subterranean drainage through the rock debris dam (Gee and Guigan 1993). The lake is becoming infilled on its western edge by an actively prograding delta of coarse fluvial gravels associated with large meltwater streams that drain late-lying snow higher in the catchment (Dumont et al. 1973).

The most important variables affecting snow and glacier mass balance are air temperatures and snow accumulation (Hughes and Braithwaite 2008). These are influenced by the climatic regime in the mountains. Wetter winters and cooler summers (as well as cooler mean annual temperatures) promote positive mass balance. Thus, any shift in climate towards increased precipitation and cooler air temperatures recorded in continuous Holocene lake and marsh sediment records will provide important insights into the viability of the High Atlas for late-lying snow and glaciers. It is also now known that the highest cirques are also likely to support sporadic permafrost (Vieira et al. 2017) and any changes in climate through the Holocene will have implications for understanding periglacial processes over this period in the High Atlas. This is especially important for testing for the possibility of active Holocene rock glaciers (Hughes 2018), which are likely to have been closely associated with former niche glaciers and ice/snowpatches.

Knowledge of changes in the state of the cryosphere in the Atlas Mountains during the Holocene is fundamental towards understanding moisture supply to the piedmonts and lowlands of Morocco. The state of the cryosphere directly impacts upon water supply which controls the ecology of the region and in turn the opportunities for human utilization of the environment through agriculture. This study will, for the first time beyond the present environment, examine the changing relationships between the state of the mountain cryosphere and regional vegetation and thus provide a 
new framework in which to view regional societal change through the Holocene.

\section{Conclusions}

It is likely that Little Ice Age glaciers and perennial or latelying snowpatches were present in Marrakech High Atlas and that these features survived, building moraines and pronival ramparts at these sites, until the mid-twentieth century. Today, snow still often survives the summer melt season in at least four sites: below the north-facing cliffs of Tazaghart (3980 m) [2 sites], Imousser (4010 m), and Annrhemer (3892 m). This highlights the fact that the High Atlas are close in altitude to the threshold for glacier survival, especially for niche glaciers in localities with favourable local topoclimatic conditions (steep north-facing hollows that favour strong shading and avalanching snow). Recent research has identified evidence for permafrost in the high cirques of Toubkal and this is likely to be the case at other sites too, including potential evidence of recent talus rock glacier activity. Research is underway to establish the timing of the last glaciers in this region and test the hypothesis that Holocene glaciers existed in these mountains and if so, when.

Acknowledgements This project is funded by a Leverhulme Research Grant (ID/Ref: RPG-2018-141). We thank Hannah Parker (July 2007), Thomas Whittaker (July 2009) and John Nudds (September 2018) for their snow reports for the highest cirques. We also thank George Hannah for his initial work in the Tazaghart area. We also thank Peter Ryan, Jeff Blackford, John Nudds, Kate Wood, Jamie Woodward, Madeleine Hann and numerous other staff and students for their discussions in Morocco over the years. We are grateful to the staff at Dar Imlil Hotel for arranging accommodation and logistics in the field. We thank Graham Bowden and Nick Scarle for drawing some of the figures. We also thank two anonymous reviewers for useful comments on the original manuscript.

\section{Compliance with ethical standards}

Conflict of interest On behalf of all authors, the corresponding author states that there is no conflict of interest.

Open Access This article is licensed under a Creative Commons Attribution 4.0 International License, which permits use, sharing, adaptation, distribution and reproduction in any medium or format, as long as you give appropriate credit to the original author(s) and the source, provide a link to the Creative Commons licence, and indicate if changes were made. The images or other third party material in this article are included in the article's Creative Commons licence, unless indicated otherwise in a credit line to the material. If material is not included in the article's Creative Commons licence and your intended use is not permitted by statutory regulation or exceeds the permitted use, you will need to obtain permission directly from the copyright holder. To view a copy of this licence, visit http://creativecommons.org/licenses/by/4.0/.

\section{References}

Adamson KR, Woodward JC, Hughes PD (2014) Glaciers and rivers: Pleistocene uncoupling in a Mediterranean mountain karst. Quat Sci Rev 94:28-43

Agence Marocaine de Presse (2020) Marrakech: Les arrivées touristiques frôlent les 3 millions en 2019. https://www.mapexpress .ma/actualite/societe-et-regions/marrakech-les-arrivees-touri stiques-frolent-les-3-millions-en-2019/. Accessed 28th April 2020

Azzioni RS, Zerboni A, Pelfini M, Garzioni CA, Cioni R, Meraldi E, Smiraglia C, Diolaiuti GA (2017) Geomorphology of Mount Ararat/Ağri Daği (Ağri Daği Milli Parki, Eastern Anatolia, Turkey). J Maps 13:182-190. https://doi.org/10.1080/17445 647.2017.1279084

Baba MW, Gascoin S, Kinnard C, Marchane A, Hanich L (2019) Effect of digital elevation model resolution on the simulation of the snow cover evolution in the High Atlas. Water Resour Res 55:5360-5378. https://doi.org/10.1029/2018WR023789

Balestrieri ML, Moratti G, Bigazzi G, Algouti A (2009) Neogene exhumation of the Marrakech High Atlas (Morocco) recorded by apatite fission-track analysis. Terra Nova 21:75-82

Ballantyne CK, Benn DI (1994) Glaciological constraints on protalus rampart development. Permafr Periglac Process 5:143-153

Barker P, Roberts N, Lamb H, van der Kaars S, Benkaddour A (1994) Interpretation of Holocene lake-level change from diatom assemblages in Lake Sidi Ali, Middle Atlas, Morocco. J Paleolimnol 12:223-234. https://doi.org/10.1007/BF00678022

Bernard J, Reille M (1987) Nouvelles analyses polliniques dans l'Atlas de Marrakech. Maroc Pollen et Spores 29(2-3):225-240

Blache J (1921) Modes of life in the Moroccan countryside: interpretations of aerial photographs. Geogr Rev 11(4):477-502

Brahim YA, Cheng H, Sifeddine A, Wassenburg JA, Cruz FW, Khodri M, Sha L, Pérez-Zanón N, Beraaouz EH, Apaéstegui J, Guyot JL (2017) Speleothem records decadal to multidecadal hydroclimate variations in southwestern Morocco during the last millennium. Earth Planet Sci Lett 476:1-10

Brahim YA, Wassenburg JA, Sha L, Cruz FW, Deininger M, Sifeddine A, Bouchaou L, Spötl C, Edwards RL, Cheng H (2019) North Atlantic ice-rafting, ocean and atmospheric circulation during the Holocene: Insights from Western Mediterranean speleothems. Geophys Res Lett 46(13):7614-7623

Boudhar A, Boulet G, Hanich L, Sicart JE, Chebouni A (2016) Energy fluxes and melt rate of a seasonal snow cover in the Moroccan High Atlas. Hydrol Sci J 61(5):931-943

Boudhar A, Duchemin B, Hanich L, Jarlan L, Chaponnière A, Maisongrande $P$ et al (2010) Long-term analysis of snow-covered area in the Moroccan High-Atlas through remote sensing. Int J Appl Earth Obs Geoinf 12:S109-S115

Boudhar A, Hanich L, Boulet G, Duchemin B, Berjamy B, Chehbouni A (2009) Evaluation of the snowmelt runoff model in the Moroccan High Atlas Mountains using two snow-cover estimates. Hydrol Sci J 54(6):1094-1113

Braithwaite RJ (2008) Temperature and precipitation climate at the equilibrium-line altitude of glaciers expressed by the degreeday factor for melting snow. J Glaciol 54:437-444. https://doi. org/10.3189/002214308785836968

Brooks D (2017) Morocco That Was 1963 to 1972 [Internet]. https ://pcmorocco1963-1972.com/2017/12/17/the-high-atlas $\%$ e2\%80\%8e/. Accessed 28th April 2020

Brown HA (1966) Return to the Atlas. Alpine J 71(313): 275-280. https://www.alpinejournal.org.uk/Contents/Contents_1966_files /AJ\%201966\%20275-280\%20Brown\%20Atlas.pdf 
Büntgen U, Myglan VS, Ljungqvist FC et al (2016) Cooling and societal change during the Late Antique Little Ice Age from 536 to around $660 \mathrm{AD}$. Nat Geosci 9:231-236

Campbell JFE, Fletcher WJ, Joannin S, Hughes PD, Rhanem M, Zielhofer C (2017) Environmental drivers of Holocene forest development in the Middle Atlas. Morocco. Front Ecol Evol 5(113):22. https://doi.org/10.3389/fevo.2017.00113

Carrera Gómez P, Valcárcel Díaz M (2013) The geomorphic action of the seasonal snow cover in the Sierra de Ancares : northeastern slope of the Pico Cuiña (León). Cuadernos de Investigación Geográfica 36(2):85-98. https://doi.org/10.18172/cig.1239

Casale A (1988) Revisione degli Sphodrina (Coleoptera, Carabidae, Sphodrini). Museo Regionale di Science Naturali, Torino, p 1024

Chardon M, Riser J (1981) Formes et processus géomorphologiques dans le Haut-Atlas marocain. Rev Geogr Alp 69:561-582

Chaponnière A, Maisongrande P, Duchemin B, Hanich L, Boulet G, Escadafal R, Elouaddat S (2005) A combined high and low spatial resolution approach for mapping snow covered areas in the Atlas mountains. Int J Remote Sens 26(13):2755-2777. https:// doi.org/10.1080/01431160500117758

Célérier J, Charton A (1922) Sur la présence de formes glaciaires dans le Haut Atlas de Marrakech. Hespéris 2:373-384

Célérier J, Charton A (1923) Un lac d'origine glaciaire dans le Haut Atlas (lac d'Ifni). Hespéris 3:501-513

Cheddadi R, Lamb HF, Guiot J, van der Kaars S (1998) Holocene climatic change in Morocco: a quantitative reconstruction from pollen data. Clim Dyn 14(12):883-890

Clark D (2012) Mountaineering in the Moroccan High Atlas: walks, climbs \& scrambles over 3000m. Cicerone Press, Milnthorpe, p 192

Cogley JG, Hock R, Rasmussen LA, Arendt AA, Bauder A, Braithwaite RJ, Janssson P, Kaser G, Möller M, Nicholson L, Zemp M (2011) Glossary of Glacier Mass Balance and Related terms, IHP-VII Technical Documents in Hydrology No. 86, IACS Contribution No. 2, UNESCO-IHP, Paris

Dee JHR, Guigan CA (1993) The limnology of Lac d'Ifni (High Atlas Mountains, Morocco), an unusually productive mountain lake. Freshw Biol 30:447-462

De Koning G (1957) Geologie des Ida ou Zal (Maroc), stratigraphie, petrographic et tectonique de la partie SW ju bloc occidental du massif ancien du Haut-Atlas. Leid Geol Med 23:1-209

De Martonne E (1924) Les formes glaciaires sur le versant Nord du Haut Atlas: Annales de Géographie (Paris, 15 Mai 1924) 183:296-302

Delcaillau B, Lavilee E, Amhrar M, Namous M, Dugué O, Pedoja K (2010) Quaternary evolution of the Marrakech High Atlas and morphotectonic evidence of activity along the Tizi N'Test Fault, Morocco. Geomorphology 118:262-279

Delcaillau B, Amrhar M, Namous M, Laville E, Pedoja K, Dugué O (2011) Transpressional tectonics in the Marrakech High Atlas: Insight by the geomorphic evolution of drainage basins. Geomorphology 134:344-362

Delhaye T.-J. (1938) La carte du massif du Toubkal au 1/20 000. Hespéris XXV: 181-198

Diao X, Dinar A, Roe T, Tsur Y (2008) A general equilibrium analysis of conjunctive ground and surface water use with an application to Morocco. Agric Econ 38:117-135

DigitalGlobe (2020) GeoEye-1. Data Sheet. https://dg-cms-uploa ds-production.s3.amazonaws.com/uploads/document/file/97/ DG_GeoEye1.pdf. Accessed 28th April 2020

Djurović P (2013) The Debeli Namet glacier from the second half of the 20th Century to the present. Acta geographica Slovenica 52(2):277-301

Dresch J (1941) Recherches sur l'évolution du relief dans le Massif Central du Grand Atlas le Haouz et le Sous: arrault et Cie. Maitres Imprimeurs, Tours, p 653
Dusserre A (2009) Une étape de la mise en carte de la montagne marocaine (1937): le massif du Toubkal au 1/20 000. Mappemonde 93. https://mappemonde.mgm.fr/num21/articles/art09105.pdf

Dumont HJ, Miron I, Dall'Asta U, Decraemer W, Claus C, Somers D (1973) Limnological aspects of some Moroccan Atlas lakes, with reference to some physical and chemical variables, the nature and distribution of the phyto- and zooplankton, inlcuding a note on possibilities for the development of an inland fishery. Int Revue der Gesamten Hydrobiol 58: 33-60

El Archi A, Jouhari A, Bouabdelli M (2003) Les formations du Massif ancien du Haut Atlas occidental marocain (Proterozoique terminal probable et Paleozoique inferieur): un jalon entre l'Anti Atlas et les domaines septentrionaux de la Meseta marocaine. Africa Geosci Rev 10:389-398

Esper J, Frank D, Büntgen U, Verstege A, Luterbacher J, Xoplaki E (2007) Long-term drought severity variations in Morocco. Geophys Res Lett 34:1-5. https://doi.org/10.1029/2007GL030844

Fletcher WJ, Zielhofer C (2013) Fragility of Western Mediterranean landscapes during Holocene Rapid Climate Changes. CATENA 103:16-29. https://doi.org/10.1016/j.catena.2011.05.001

Fletcher WJ, Hughes PD (2017) Anthropogenic trigger for Late Holocene soil erosion in the Jebel Toubkal, High Atlas, Morocco. CATENA 149:713-726

Fletcher W, Zielhofer C, Mischke S, Bryant C, Xu X, Fink D (2017) AMS radiocarbon dating of pollen concentrates in a karstic lake system. Quat Geochronol 39:112-123

Gachev E, Stoynaov K, Gikov A (2016) Several small glaciers on the Balkan Peninsula: state and changes in the last several years. Quatern Int 415:33-54

Gómez-Ortiz A, Palacios D, Schulte L et al (2009) Evidences from historical documents of landscape evolution after little ice age of a Mediterranean high mountain area, Sierra Nevada, Spain (eighteenth to twentieth centuries). Geogr Ann Ser A Phys Geogr 91:279-289. https://doi.org/10.1111/j.1468-0459.2009.00370.x

Grunewald K, Scheithauer J (2010) Europe's southernmost glaciers: response and adaptation to climate change. J Glaciol 42:3-18

Hannah G (2014) Quaternary glacial history of the Toubkal massif, High Atlas, North Africa. M.Phil thesis. March 2014. Corpus Christi College, University of Cambridge. 145 pp.

Hannah G, Hughes PD, Gibbard PL (2017) Pleistocene plateau ice fields in the High Atlas, Morocco. In: Hughes PD, Woodward JC (ed) Quaternary glaciation in the mediterranean mountains. Geological Society, Special Publications, London, pp 433: 25-53. https://doi.org/10.1144/SP433.12

Harden JW (1982) A quantitative index of soil development from field descriptions: examples from a chronosequence in central California. Geoderma 28:1-28

Harris I, Jones PD, Osborn TJ, Lister DH (2014) Updated high-resolution grids of monthly climatic observations - the CRU TS3.10 dataset. Int J Climatol 34:623-642

Hedding DW (2016) Pronival ramparts: a review. Prog Phys Geog 40:835-855

Hernando C, Ribera I, Vogler AP (1999) Alpine and cave or endogean habitats as postglacial refugia: examples from palearctic ground beetles, with comments on their possible origins (Coleoptera: Carabidae). The Coleopterists Bulletin 53:31-39

Hill DF, Burakowski EA, Crumley RL, Keon J, Hu M, Arendt AA, Wikstrom Jones K, Wolken GJ (2019) Converting snow depth to snow water equivalent using climatological variables. Cryosphere 13:1767-1784. https://doi.org/10.5194/tc-13-1767-2019

Hock R (2003) Temperature index melt modelling in mountain areas. J Hydrol 282:104-115

Hooker JD, Ball J (1878) Journal of a tour in Marocco and the Great Atlas, with an appendix including a sketch of the geology of Marocco, by George Maw, Macmillan \& Co, London, pp 499. 
Hughes PD (2009) Twenty-first century glaciers in the Prokletije Mountains, Albania. Arct Antarct Alp Res 41:455-459

Hughes PD (2010) Little Ice Age glaciers in Balkans: low altitude glaciation enabled by cooler temperatures and local topoclimatic controls. Earth Surf Proc Land 5:229-241

Hughes PD (2014) Little Ice Age glaciers in the Mediterranean mountains. Mediterranée 122:63-79

Hughes PD (2018) Little Ice Age glaciers and climate in the Mediterranean mountains: a new analysis. Cuadernos de Investigación Geográfica 44:15-45. https://doi.org/10.18172/cig.3362

Hughes PD (2007) Recent behaviour of the Debeli Namet glacier, Durmitor, Montenegro. Earth Surf Proc Land 10:1593-1602

Hughes PD (2008) Response of a Montenegro glacier to extreme summer heatwaves in 2003 and 2007. Geogr Ann 90A:259-267

Hughes PD, Braithwaite RJ (2008) Application of a degree-day model to reconstruct Pleistocene glacial climates. Quaternary Res 69:110-116

Hughes PD, Woodward JC (2009) Glacial and periglacial environments. In: Woodward JC (ed) The physical geography of the Mediterranean. Oxford Univ Press, Oxford, pp 353-383

Hughes PD, Gibbard PL, Woodward JC (2005) Quaternary glacial records in mountain regions: a formal stratigraphical approach. Episodes 28:85-92

Hughes PD, Gibbard PL, Woodward JC (2004) Quaternary glaciation in the Atlas Mountains, North Africa. In: Ehlers J, Gibbard PL (eds) Quaternary glaciation—extent and chronology: Asia, Latin America, Africa, Australia, Antarctica, vol 3. Elsevier, Amsterdam, pp 255-260

Hughes PD, Woodward JC, Gibbard PL, Macklin MG, Gilmour MA, Smith GR (2006) The glacial history of the Pindus Mountains, Greece. J Geol 114:413-434

Hughes PD, Fenton CR, Gibbard PL (2011) Quaternary glaciations of the Atlas Mountains, North Africa. In: Ehlers J, Gibbard PL, Hughes PD (eds) Quaternary glaciations-extent and chronology, part IV—a closer look. Elsevier, Amsterdam, pp 1071-1080

Hughes PD, Fink D, Fletcher WJ, Hannah G (2014) Catastrophic rock avalanches in a glaciated valley of the High Atlas, Morocco: ${ }^{10} \mathrm{Be}$ exposure ages reveal a $4.5 \mathrm{ka}$ seismic event. Geol Soc Am Bull 126:1093-1104

Hughes PD, Fink D, Rodés Á, Fenton CR, Fujioka T (2018) ${ }^{10} \mathrm{Be}$ and ${ }^{36} \mathrm{Cl}$ exposure ages and palaeoclimatic significance of glaciations in the High Atlas, Morocco. Quat Sci Rev 180:193-213

Hughes PD, Fink D, Fletcher W (2020) Untangling the Quaternary Period: A Legacy of Stephen C. Porter. In: Waitt RB, Thackray GD, Gillespie AR (eds) Geological Society of America Special Paper 548. https://doi.org/10.1130/2020.2548(08)

JICA (2004) Etude du plan directeur sur le systeme de prevision et d'alerte aux crues pour la region de l'Atlas au Royaume du Maroc : rapport definitif. Vol. 3. -Rapports annexes. Agence Japonaise de Cooperation Internationale : CTI Engineering International Co., Ltd. : Yachiyo Engineering Co., Ltd. http://openj icareport.jica.go.jp/617/617/617_411_11750874.html. Accessed 28th April 2020

Kerr RA (2000) A North Atlantic climate pacemaker for the centuries. Science 288(5473):1984-1985

Lamb HF, van der Kaars S (1995) Vegetational response to Holocene climatic change: pollen and palaeolimnological data from the Middle Atlas. Morocco The Holocene 5(4):400-408

Lamb H, Eicher U, Switsur VR (1989) An 18,000-year record of vegetation, lake-level and climatic change from Tigalmamine, Middle Atlas. Morocco J Biogeogr 16(1):65-74

Lamb HF, Duigan CA, Gee JHR, Kelts K, Lister G, Maxted R, Merzouk A, Niessen F, Tahiri M, Whittington RJ, Zeroual E (1994) Lacustrine sedimentation in a high-altitude, semi-arid environment: the palaeolimnological record of Lake Isli, High Atlas, Morocco. In: Millington AC, Pye K (eds) Environmental change in drylands: biogeographical and geomorphological perspectives. Wiley, Chichester, pp 148-161

Lamb HF, Gasse F, Benkaddour A, El Hamouti N, van der Kaars S, Perkins WT, Pearce NJ, Roberts CN (1995) Relation between century-scale holocene arid intervals in tropical and temperate zones. Nature 373(6510):134-137

Lamb H, Roberts N, Leng M, Barker P, Benkaddour A, van der Kaars S (1999) Lake evolution in a semi-arid montane environment: response to catchment change and hydroclimatic variation. $\mathrm{J}$ Paleolimnol 21(3):325-343

Lang H, Braun L (1990) On the information content of air temperature in the context of snowmelt estimation. In: Molnar L, (ed), Hydrology of Mountainous areas, proceedings of the Strbske Pleso Symposium 1990: IAHS Publ. no. 190, pp 347-354.

Lliboutry L (1954) The origin of penitents. J Glaciol 2:331-338

Lopez-Moreno JI, Gascoin S, Herrero J, Sproles EA, Pons M, AlonsoGonzález E et al (2017) Different sensitivities of snowpacks to warming in Mediterranean climate mountain areas. Environ Res Lett 12:074006. https://doi.org/10.1088/1748-9326/aa70cb

Marchane A, Jarlan L, Hanich L, Boudhar A, Gascoin S, Tavernier A et al (2015) Assessment of daily MODIS snow cover products to monitor snow cover dynamics over the Moroccan Atlas Mountain range. Remote Sens Environ 160:72-86

Messerli B (1967) Die eiszeitliche und die gegenwartige Vertgletscherung im Mittelemeeraum. Geogr Helv 22:105-228

Ministere de l'Agriculture et de la Mise en Valeur Agricole (1994) Jbel Toubkal. Feuille NH-29-XXIII-1a.

N'da AB, Bouchaou L, Reichert B, Hanich L, Brahim YA, Chehbouni A, Beraaouz EH, Michelot J-L (2016) Isotopic signatures for the assessment of snow water resources in the Moroccan High Atlas Mountains: contribution to surface and groundwater recharge. Environ Earth Sci 75:755. https://doi.org/10.1007/ s12665-016-5566-99

NOAA (2020) National Centers for Environmental Information, National Oceanic and Atmospheric Administration. Climate Data Online: Morocco. https://www.ncdc.noaa.gov/cdo-web/datasets/ GHCND/locations/FIPS:MO/detail. Accessed 28th April 2020

Nour el Bait M, Rhoujjati A, Benkaddour A, Carré M, Eynaud F, Martinez P, Cheddadi R (2016) Climate change and ecosystems dynamics over the last 6000 years in the Middle Atlas. Morocco Clim Past 12(4):1029-1042

Nour el Bait M, Rhoujjati A, Eynaud F, Benkaddour A, Dezileau L, Wainer K, Goslar T, Khater C, Tabel J, Cheddadi R (2014) An 18 000-year pollen and sedimentary record from the cedrus forests of the Middle Atlas. Morocco J Quat Sci 29(5):423-432

Oliva M, Gómez-Ortiz A, Palacios D, Salvador-Franch F, de Andrés N, Tanarro LM, Fernández- Fernández JM, Barriocanal C (2020) Multiproxy reconstruction of Holocene glaciers in Sierra Nevada (south Spain). Mediterranean Geosci Rev. https://doi. org/10.1007/s42990-019-00008-2

Palacios D, de Andrés N, Luengo E (2003) Distribution and effectiveness of nivation in Mediterranean mountains: Peñalara (Spain). Geomorphology 54:157-178

Parish R, Funnell DC (1999) Climate change in mountain regions: some possible consequences in the Moroccan High Atlas. Global Environ Chang 9:45-58

Peyron M (1980) Les chutes de neige dans 1'Atlas marocain. Rev de Géogr Alp 68:237-254

Peyron M (2010) Michael Peyron's Berber website [Internet]. http:// michaelpeyron.unblog.fr/2010/12/06/varappes-modestes-etcourses-de-neige-faciles-dans-le-haut-atlas-atlas-marocain/. Accessed 28th April 2020

Pouclet A, Aarab A, Fekkak A, Benharraf M (2007) Geodynamic evolution of the northwestern Paleo-Gondwanan margin in the Morocco Atlas at the PreCambrian-Cambrian boundary. Geol Soc Spec Publ 423:27-60 
Proust F (1973) Étude stratigraphique, pétrographique et structurale du Bloc oriental du Massif ancien du Haut Atlas (Maroc): Notes et Mémoires. Service Géologique du Maroc 34:15-53

Rackham H (1942) Pliny. Natural History, Volume II: Books 3-7. Translated by H. Rackham. Loeb Classical Library 352. Cambridge, MA: Harvard University Press, 1942. pp 223

Reille M (1976) Analyse pollinique de sédiments postglaciaires dans le Moyen Atlas et le Haut Atlas marocains: premiers résultats. Ecol Mediterranea 2:153-170

Reille M, Pons A (1992) The ecological significance of sclerophyllous oak forests in the western part of the Mediterranean basin: a note on pollen analytical data. Vegetatio 99(100):13-17

Rhoujjati A, Cheddadi R, Taïeb M, Baali A, Ortu E (2010) Environmental changes over the past c. 29,000 years in the Middle Atlas (Morocco): a record from Lake Ifrah. J Arid Environ 74(7):737-745

Ros RM, Cano MJ, Muñoz J, Guerra J (2000) Contribution to the bryophyte flora of Morocco: the Jbel Toubkal. J Bryol 22(4):283-289. https://doi.org/10.1179/jbr.2000.22.4.283

Ruiz B, Gil MJ, Duque D (2015) Vegetation history in the Oukaïmeden valley. Human action and the evolution of the landscape. Complutum 25(2):123-137

Sarıkaya MA, Tekeli AE (2014) Satellite inventory of glaciers in Turkey. In: Kargel JS, Leonard GJ, Bishop MP, Kääb A, Raup B (eds) Global Land Ice Measurements from Space. PraxisSpringer, Berlin, pp 465-480. https://doi.org/10.1007/978-3540-79818-7

Schimmelpfennig I, Schaefer JM, Akçar N, Koffman T, Ivy-Ochs S, Schwartz R, Finkel RC, Zimmerman S, Schlüchter C (2014) A chronology of holocene and little ice age glacier culminations of the Steingletscher, Central Alps, Switzerland, based on high-sensitivity beryllium-10 moraine dating. Earth Planet Sci Lett 393:220-230

Schulz O, de Jong C (2004) Snowmelt and sublimation: field experiments and modelling in the High Atlas Mountains of Morocco. Hydrol Earth Syst Sc 8:1076-1089

Serrano E, González-Trueba JJ, Sanjosé JJ, Del Río LM (2011) Ice patch origin, evolution and dynamics in a temperate high mountain environment: the Jou Negro, Picos de Europa (NW Spain). Geogr Ann A93:57-70

Simonneaux V, Hanich L, Boulet G, Thomas S (2008) Modelling runoff in the Rheraya Catchment (High Atlas, Morocco) using the simple daily model GR4J. Trends over the last decades. 13th IWRA World Water Congress. Montpellier, France.

Smith K (2004) Trekking in the Atlas Mountains. Cicerone Press, Milnthorpe, p 160

Society for the diffusion of useful knowledge (Great Britain) (1836) North Africa or Barbary I. Morocco. (with) Plan of the City of Marocco. Published under the superintendence of the Society for the Diffusion of Useful Knowledge. Engraved by J. \& C.
Walker. London, published by Baldwin \& Cradock, 47 Paternoster Row, April 1st. 1836. Printed by Russell, Penge, Surrey. London: Chapman \& Hall

Sturm M, Taras B, Liston GE, Derksen C, Jonas T, Lea J (2010) Estimating snow water equivalent using snow depth data and climate classes. J Hydrometerol 11:1380-1394

Tabel J, Khater C, Rhoujjati A, Dezileau L, Bouimetarhan I, Carre M, Vidal L, Benkaddour A, Nourelbait M, Cheddadi R (2016) Environmental changes over the past 25,000 years in the southern Middle Atlas. Morocco J Quat Sci 31(2):93-102

Thomson J (1889) The ascent of Tizi Likumpt. In: Travels in the Atlas and southern Morocco: A narrative of exploration. George Philip \& Co, London, $\mathrm{p} 456-467$

Thomson J (1899) The geology of southern Morocco and the Atlas Mountains. Q J Geol Soc 55(1-4):190-213

US Army Map Service (1943) Tahanout. Sheet 19. 1:125,000. Compiled from Service Géographique du Maroc 1:100,000, 1937 to 1940, Chief of Engineers, US Army, Army Map Service, Cleveland Unit, 1942-1943

Vieira G, Mora C, Faleh A (2017) Ground surface temperatures indicate the presence of permafrost in North Africa (Djebel Toubkal, High Atlas, Morocco). Cryosphere 11: 1691-1705. https://www. the-cryosphere-discuss.net/tc-2016-234/

Walter H, Lieth H (1967) Climate diagram world atlas. Gustav Fischer, Jena

Washington L (1831) Geographical notice of the Empire of Marocco. J R Geograph Soc Lond 1:23-155

Wassenburg JA, Immenhauser A, Richter DK, Niedermayr A, Riechelmann S, Fietzke J, Scholz D, Jochum KP, Fohlmeister J, Schröder-Ritzrau A, Sabaoui A, Riechelmann DFC, Schneider L, Esper J (2013) Moroccan speleothem and tree ring records suggest a variable positive state of the north atlantic oscillation during the medieval warm period. Earth Planet Sc Lett 375:291-302

Zielhofer C, Fletcher WJ, Mischke S, De Batist M, Campbell JFE, Joannin S, Tjallingii R, El Hamouti N, Junginger A, Stele A, Bussmann J, Schneider B, Lauer T, Spitzer K, Strupler M, Brachert T, Mikdad A (2017a) Atlantic forcing of Western Mediterranean winter rain minima during the last 12,000 years. Quat Sci Rev 157:29-51

Zielhofer C, von Suchodoletz H, Fletcher WJ, Schneider B, Dietze E, Schlegel M, Schepanski K, Weninger B, Mischke S, Mikdad A (2017b) Millennial-scale fluctuations in Saharan dust supply across the decline of the African Humid Period. Quat Sci Rev 171:119-135

Publisher's Note Springer Nature remains neutral with regard to jurisdictional claims in published maps and institutional affiliations. 